\title{
Cocoa Pod Husks as Potential Sources of Renewable High-Value-Added Products: A Review of Current Valorizations and Future Prospects
}

\author{
Leygnima Yaya Ouattara, ${ }^{\mathrm{a}, *}$ Esaie Kouadio Appiah Kouassi, ${ }^{\mathrm{a}}$ Doudjo Soro, ${ }^{\mathrm{a}}$ \\ Yaya Soro, ${ }^{a}$ Kouassi Benjamin Yao, ${ }^{a}$ Kopoin Adouby, ${ }^{a}$ Allali Patrick Drogui, ${ }^{b}$ \\ Dayal Rajeshwar Tyagi, ${ }^{b}$ and Pepin Martin Aina ${ }^{c}$
}

\begin{abstract}
Cocoa is among the most cultivated and important tropical crops in the world, and it is economically viable in the agro-pastoral systems of tropical Africa. Further, the amount of cocoa residue is steadily increasing due to the strong worldwide demand for chocolate products. This review of cocoa residue found that an average of 18 publications per year were published in the last 10 years. The most common type of publication on cocoa pod husks $(\mathrm{CPH})$ was newspaper articles, which comprised $50 \%$ of the publications. This review examines the use of CHP in sustainable development, agrochemical materials, and agro-materials through their potential valorizations into high value-added products. Indeed, $\mathrm{CPH}$ is an abundant, accessible, and renewable resource of bioproducts, dietary fibers, nutraceuticals, functional foods, pectin, antioxidant compounds, theobromine, and minerals. Potential food applications of $\mathrm{CPH}$ include the production of flavor compounds, gums, texturing agents, and others. The production of biomaterials for food and non-food use, biofuels, and organic acids, such as lactic acid (the polymerization of which produces the PLA used in bioplastic production), are several potential areas for the biotechnological development of $\mathrm{CPH}$ and its fractions.
\end{abstract}

Keywords: Cocoa pod husks; Pretreatment; Conversion; High value-added products; Biocomposite

Contact information: a: Laboratoire des Procédés Industriels de Synthèse, de l'Environnement et des Energies Nouvelles (LAPISEN), Unité Mixte de Recherche et d'Innovation en Sciences des Procédés Chimiques, Alimentaires Environnementaux et énergétiques, Institut National Polytechnique Félix Houphouët-Boigny, Yamoussoukro, Côte d'Ivoire; b: Institut National de la Recherche Scientifique (INRS Eau Terre et Environnement), Université du Québec, 490 rue de la Couronne, Québec City, Canada; c: Laboratoire des Sciences et Techniques de l'Eau (LSTE)/ Institut National de l'Eau (INE), Université d'Abomey-Calavi (UAC), 01 BP 2009 Cotonou, Benin;

* Corresponding author: leygnima.ouattara18@inphb.ci

\section{INTRODUCTION}

Environmental pollution is among the most serious problems facing humanity today (Cho et al. 2020). A fundamental problem linked to pollution is the elimination of the large quantities of organic waste that are continuously produced (Cho et al. 2020). Solving the problem of large quantities of organic waste or secondary raw materials is a necessity (Balentić et al. 2018). Consequently, specific applications are needed to use these raw materials in the most efficient way possible in the production process. The concepts of "wealth-generating waste" and "recyclable materials" are important for building a sustainable and healthy society through the efficient use of these waste resources (Daud et al. 2013). As global production of Theobroma cocoa beans (Malvaceae) has decreased, the 
governments of several tropical countries (Vriesmann et al. 2011a) have strongly expressed their support for the expansion of the cocoa industry by encouraging cocoa farmers to plant additional trees. This initiative has led to an increase of more than $50 \%$ in the production of cocoa beans (Uy et al. 2019). However, the increase in production has also favored the proliferation of undesirable residues, such as cocoa pod husks, on cocoa farms and plantations. In addition, as petroleum resources continue to decrease and the environmental concerns caused by petroleum products grow, research (Vásquez et al. 2019) has focused on the capacity of cocoa pod husks to produce biofuels and other biopolymers. However, cocoa pod husk $(\mathrm{CPH})$ remains under-exploited, as it is a renewable resource rich in dietary fiber, lignin, and bioactive antioxidants, such as polyphenols (Lu et al. 2018).

The recovery of lignocellulosic fractions and bioactive compounds from cocoa pod husks can lead to the development of profitable basic products. Consequently, these cocoa pod husks can generate income for farmers and promote economic development (Lu et al. 2018).

This review article first focuses on analyzing bibliometric data to determine the trends, research priorities, current topics, and important research areas of cocoa pod husks. Then, the stages in the development of $\mathrm{CPH}$ are presented to summarize the mineral and biochemical composition of CPH. The main pretreatment strategies and the different ways of converting cocoa pod husks are also reviewed. Finally, the current state of CPH valorization and future perspectives on $\mathrm{CPH}$ valorization are discussed.

\section{Dynamics of the Production of Beans and Cocoa Pod Husks}

Approximately 50 countries produce cocoa, and the Ivory Coast is the largest producer. Figure 1 (International Cocoa Organization (ICCO)) shows the evolution of cocoa production in west Africa. The African continent alone supplies approximately $74 \%$ of cocoa produced globally. Among various countries of Africa, Ivory Coast is the biggest producer of cocoa (42\%), followed by Ghana (20\%), Nigeria (6\%), and Cameroon (5\%). Figure 1 provides the statistics of cocoa production in cocoa-producing countries. However, Ivory Coast suffers many consequences due to its immense production.

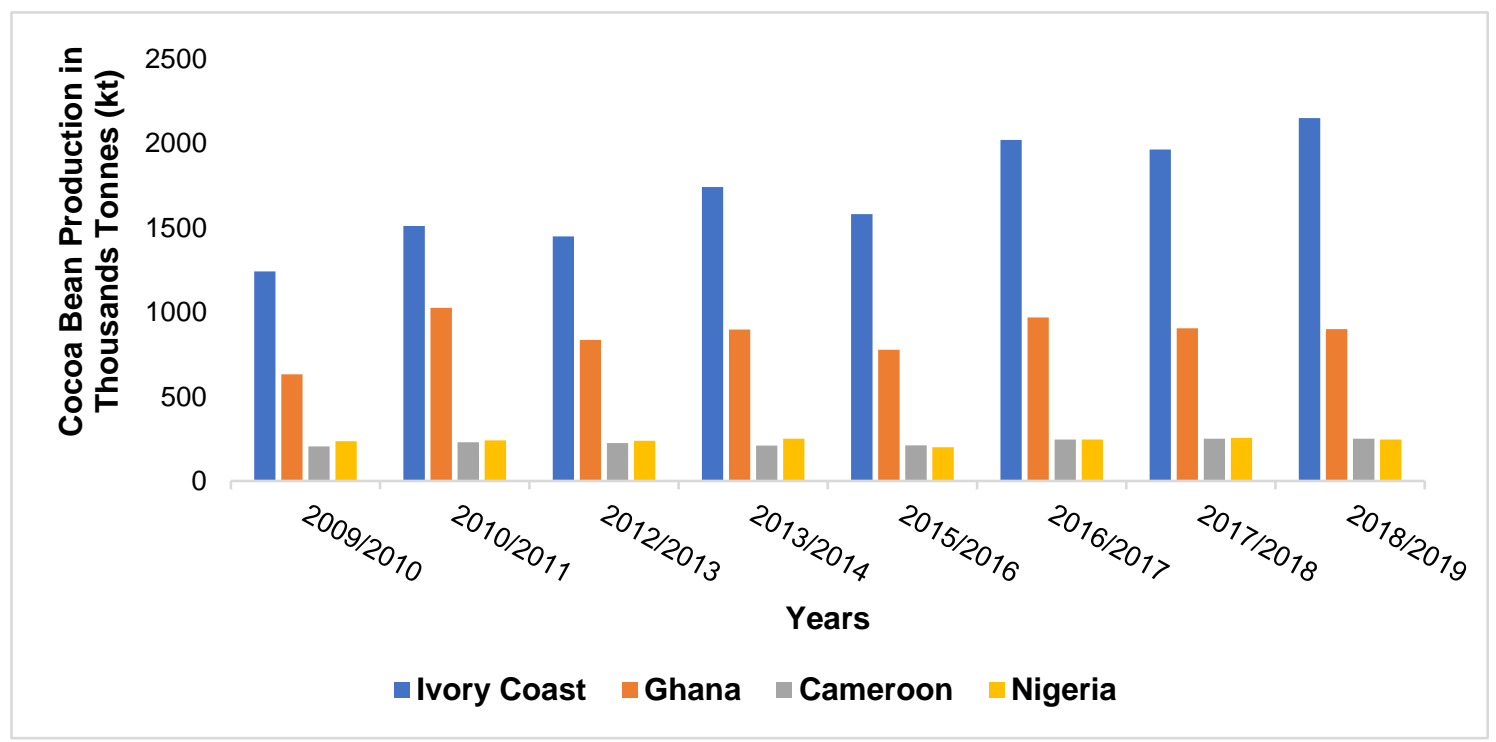

Fig. 1. Quantity of cocoa beans per y in the main producing countries of West Africa (International Cocoa Organization (ICCO) 2019) 
In fact, 10 tonnes of wet pods are generated for each tonne of dry cocoa beans (Campos-Vega et al. 2018). Therefore, a large area is necessary for disposal, and the wet pods represent a major challenge for waste management. Currently, in Ghana and Ivory Coast, approximately $1 \%$ of this biomass is used to make soap (Antwi et al. 2019).

Figure 2 shows the amounts of beans and cocoa pods husks produced in the main cocoa-bean producing countries during the 2018/2019 campaign. As Ivory Coast produced approximately 6,500,000 tonnes of $\mathrm{CPH}$, it now must manage this waste, which is generally stored in fields, and its decomposition attracts flies and other insects harmful to cocoa. Furthermore, the decomposition of these residues is a potential source of pathogenic microorganisms, such as black pod disease (Mansur et al. 2014), which is caused by Phytophthora palmivora and $P$. megakarya fungi. The disease causes an estimated annual yield loss of $20 \%$ to $30 \%$ worldwide, whereas individual farms may experience an annual yield loss of $30 \%$ to $90 \%$ (Lu et al. 2018).

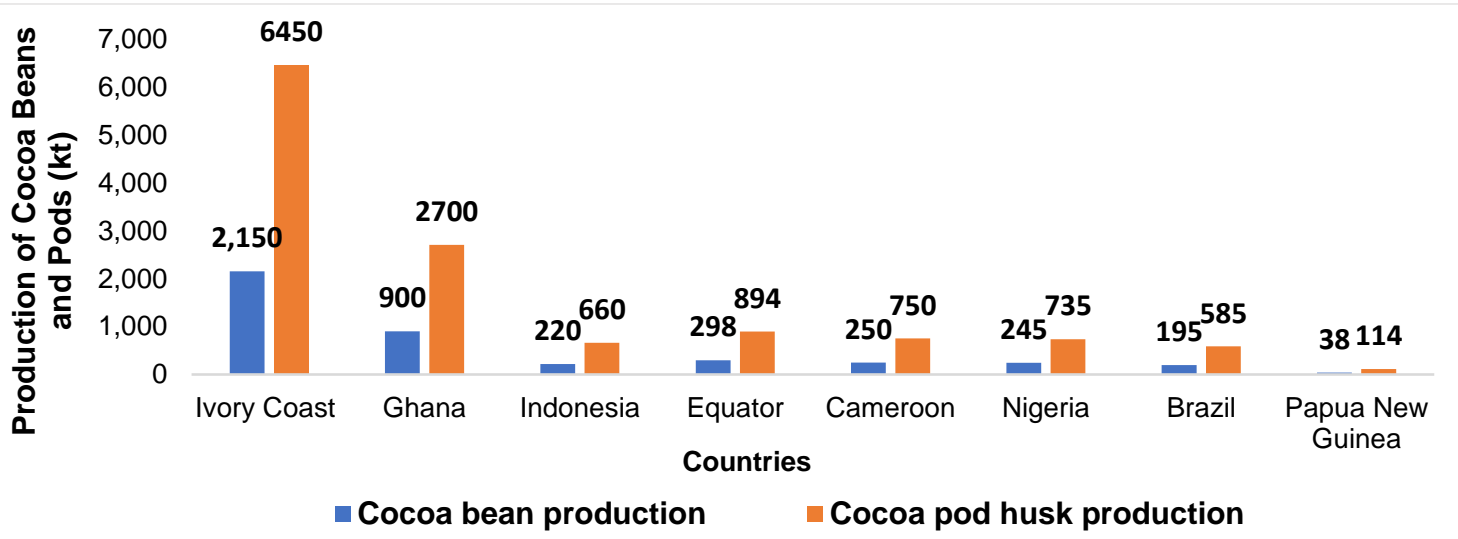

Fig. 2. Production of cocoa beans and residual pod by country during 2018 and 2019 (Statista 2019)

Cocoa pod husk is a lignocellulosic biomass that is rich in minerals (in particular, potassium), fibers (especially lignin, cellulose, hemicellulose, and pectin), and antioxidants (phenolic acids, etc.) (Kouakou et al. 2018). However, it is still largely under-exploited. Appropriate use of this lignocellulosic material could offer economic benefits and reduce its environmental impact (Adjin-Tetteh et al. 2018).

\section{Description of CPH}

The $\mathrm{CPH}$ is the outer part of the fruit (exocarp), which has an oval, rough, and relatively thick appearance (Fig. 3 and Fig. 4).

Cocoa pod husk comes in different colors depending on the variety, and its roughness protects it against the elements, plagues, and damage that could be caused by impact (Vásquez et al. 2019). It is obtained after husking and removing the beans, and it represents $70 \%$ to $80 \%$ of the dry weight of the whole fruit. This natural, layered material comprises three distinct layers (Fig. 4), which are the epicarp, the mesocarp, and the endocarp, which constitute the outer, middle, and inner pericarp, respectively (CamposVega et al. 2018). The endocarp is the innermost part and occurs as a soft, whitish tissue that protects the cocoa beans in a well-lubricated inner chamber (Campos-Vega et al. 2018). The mesocarp has a hard composite structure capable of holding the cocoa beans in place even in severe conditions. 


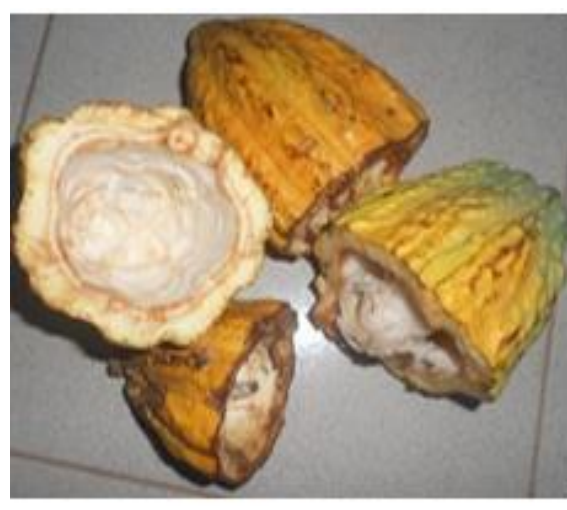

Fig. 3. Cocoa pod husks

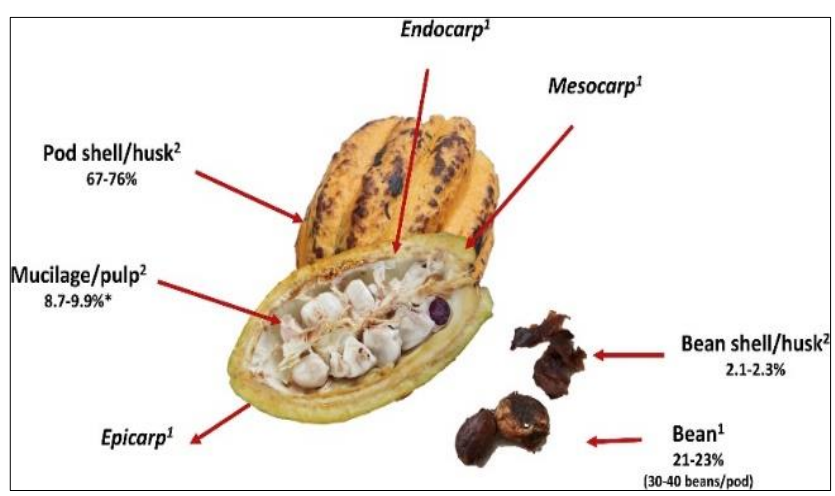

Fig. 4. Different parts of $\mathrm{CPH}$ (Reprinted with permission; Campos-Vega et al. 2018)

The relatively soft outermost layer is the yellow (or purplish red upon maturity) cover, and it is this part that is exposed to the sun. When it turns black, this indicates that the fruit is rotting and dry (Babatope 2005).

\section{Bibliometric Study on the Cocoa Pod Husk}

Bibliometric analysis is a useful tool for analyzing publications in several areas of research (Maassen 2016). It is a quantitative approach of studying the metadata of scientific publications (Maassen 2016). It is a useful method for detecting research trends in a given area (Maassen 2016). It concerns three elements of scientific activity, which are its inputs, its outputs, and its impacts. It allows an assessment of scientific activity and the place of actors in relation to a given theme. This new scientific approach has been increasingly used and considered before undertaking studies on a given theme.

In this study, several word combinations were searched to identify themes from 2005 to 2019, which included "cocoa pods," "cocoa pod husks," and "cocoa residues." With this method, it was possible to overcome the weaknesses of individual keyword analysis and identify relevant points and current search trends in different countries (Maassen 2016) for a given theme. This bibliometry on CHP was produced on 05/07/2019 with the internet platform SCIFINDER that lists all forms of publication dealing with the topic to be addressed. This database allowed assessment of the scientific interest in the subject of $\mathrm{CPH}$. A total of 268 publications met the selection criteria. The selected publications were then analyzed according to the characteristics of the articles (type of document, country of origin, and citations), publication models (main journals and journal category), the importance of research (number of publications per year), the number of publications per author, and the areas of valuation (Maassen 2016).

\section{Number of Publications per Year}

Interest in CPH began in 1905 with a single publication. However, an increased interest in CPH began in 2003 and has continued to grow (Fig. 5). Over the past $10 \mathrm{y}$, an average of 18 publications per year have been produced on $\mathrm{CPH}$. Over the past $5 \mathrm{y}$, an average of 24.2 publications per year were produced. This growing interest in cocoa pod husks is probably due to the increasing amount of this residue in the fields, which is becoming an environmental problem. Further, the enormous losses caused to cocoa farmers due to cocoa diseases, such as brown and black pod rot, have likely driven this interest. 


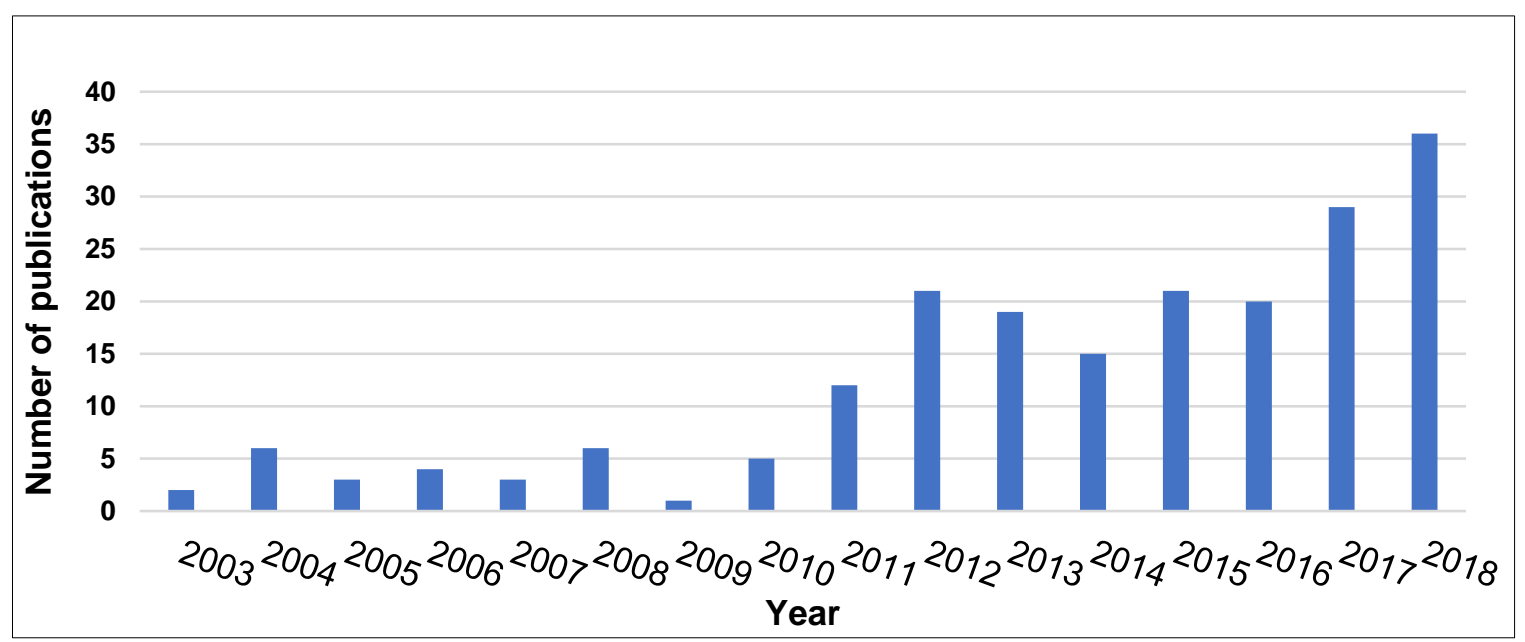

Fig. 5. Number of publications produced annually related to $\mathrm{CPH}$

In addition, the demand for chocolate-based products has led cocoa-producing countries to increase their production, which has resulted in increased waste products, such as $\mathrm{CPH}$, which constitutes approximately $76 \%$ of the weight of whole pods (Chun and Husseinsyah 2016). Several studies have shown that 10 tonnes of CPH are produced as waste for every tonne of cocoa beans (Mansur et al. 2014; Sanyang et al. 2017). Therefore, the theme related to this material was topical and relevant to the interest of researchers.

\section{Work Density by Publishing Type}

The most common type of publication on $\mathrm{CPH}$ was journal articles, which comprised 54\% of the publications (Fig. 6). Therefore, $\mathrm{CPH}$ has great potential and requires further exploration based on the number of patents filed (12), which represented $15 \%$ of publications. A single bibliographic review article was produced on $\mathrm{CPH}$, which looked at the biotechnological recovery of all residual biomass from the cocoa industry (Vásquez et al. 2019) and justified the present study. Figure 6 illustrates the distribution of publication types.

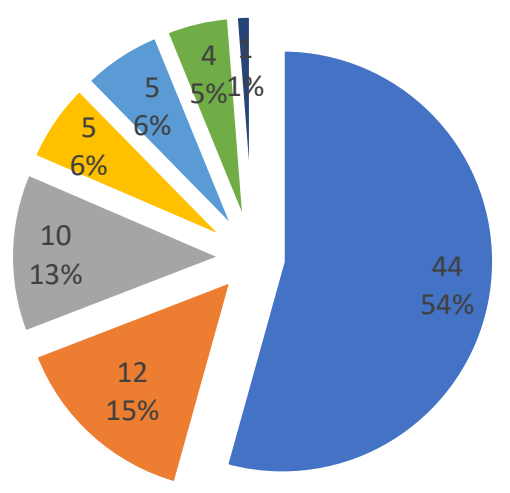

- Journal Article

- Patent

- Research Support Nonus Govt

- Conference

- General Review

- Meeting Abstract

- Review

Fig. 6. Density of works by type of publication 


\section{Areas of Valorization for Cocoa Pod Husks}

The valorization of $\mathrm{CPH}$ has aroused interest in several fields, including radial electrochemical agrochemical bioregulators, thermal energy technology, soil fertilization, plant nutrition, food and animal chemistry, plastic treatment, and waste treatment and disposal (Fig. 7).

The large numbers of publications in the fields of soil fertilization, plant nutrition, food and feed chemistry, plastics manufacturing and processing, and waste treatment and disposal were justified by the rich mineral and fibre composition of this biomass. Several of these areas (soil fertilization, plant nutrition, and food and feed chemistry) have already been widely exploited and others (plastic manufacturing and processing) are still under study and deserve special attention.

The recovery of $\mathrm{CPH}$ begins with the harvest of the material, followed by drying. Indeed, the moisture content of the fresh pod is approximately $90 \%$ (Vriesmann et al. 2011a).

Therefore, quick drying is essential to avoid deterioration. Finally, the CPH residues are ground. A complete characterization (physico-chemical, biochemical, and thermal) and an appropriate delignification process are necessary to better explore the lignocellulosic components of $\mathrm{CPH}$ to identify the appropriate pathway for the residue.

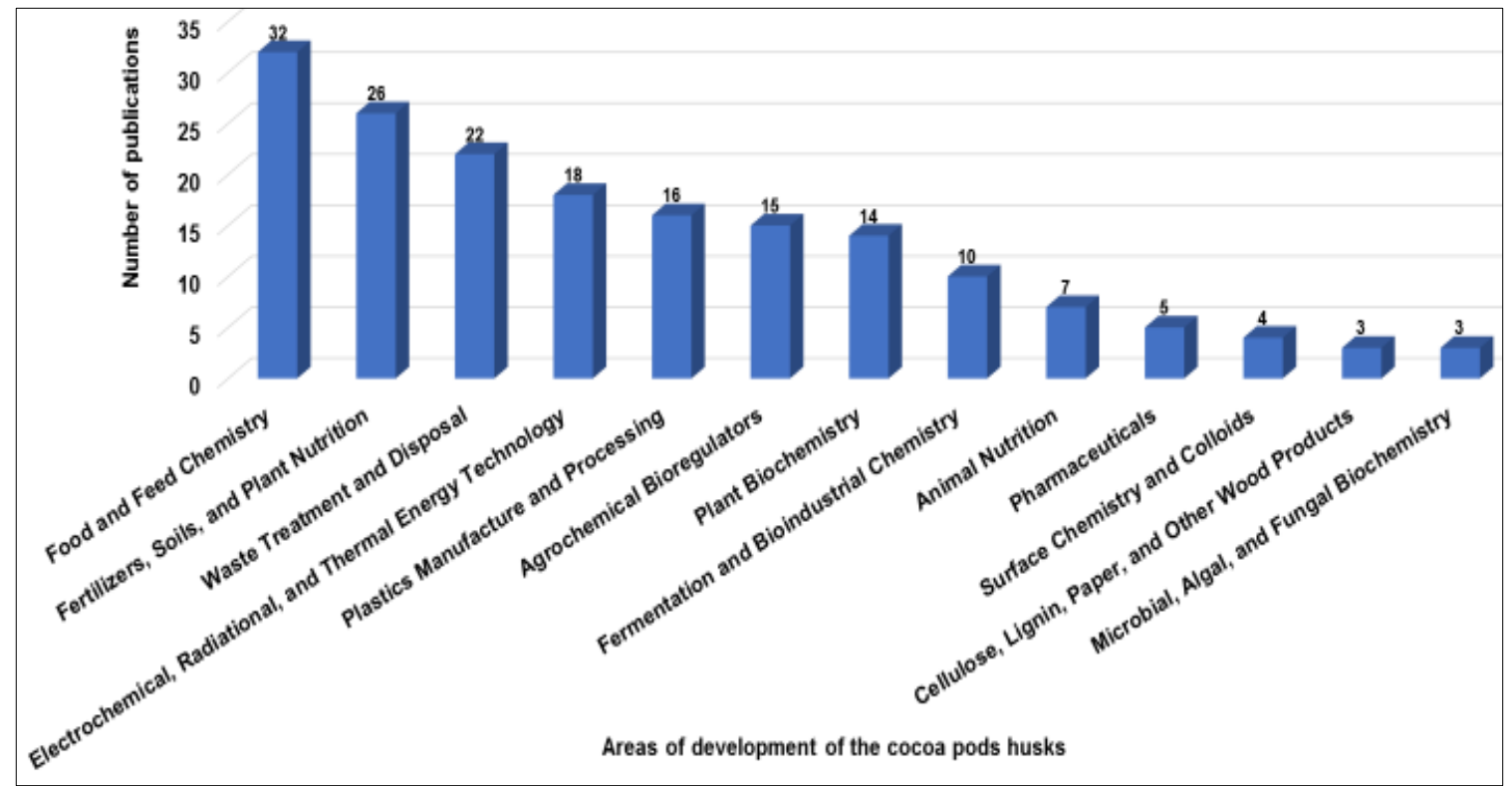

Fig. 7. Publications of the Index of Scientific quotes based on the areas of $\mathrm{CPH}$ valuation

\section{Cocoa Pod Husks Valorization Process}

Chemical, Physico-chemical, and Biochemical Characterization Process of Cocoa Pod Husks

Figure 8 schematically illustrates the valorization process of CPH in value-added products. Several works have focused on the physico-chemical (Vásquez et al. 2019), thermochemical (Adjin-Tetteh et al. 2018), and biochemical (Giwa et al. 2020), characterization of $\mathrm{CPH}$ to identify the appropriate conversion pathways. Cocoa pod husks were found to be rich in raw energy, cellulose, hemicellulose, potassium, and many other minerals useful for soil improvement. 


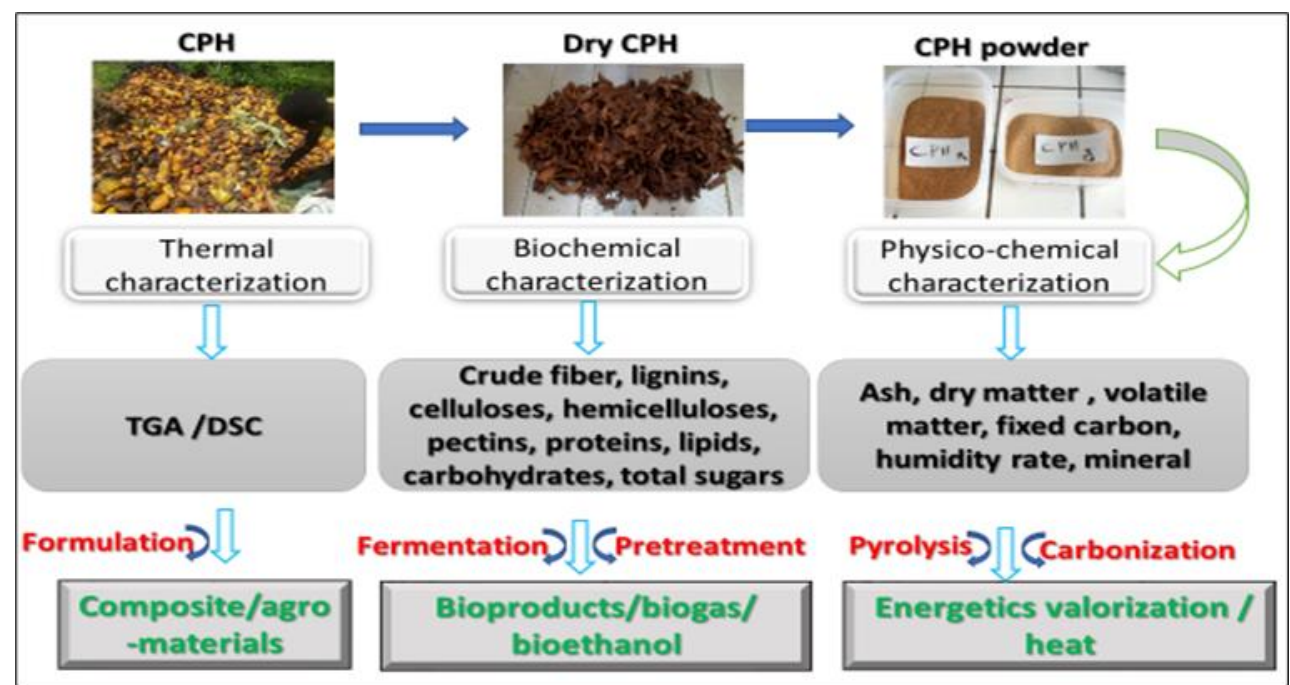

Fig. 8. Schematic representation of the characterization procedures of cocoa pod husks

Table 1 summarizes the proximal composition of $\mathrm{CPH}$ obtained in several regions of the world after its characterization.

Table 1. Composition of Cocoa Pod Husks in Previous Studies

\begin{tabular}{|c|c|c|c|c|}
\hline Volatile Matter (\%) & Ash (\%) & Moisture (\%) & Cfixe $(\%)$ & Reference \\
\hline 58.46 & 13.21 & 11.53 & 16.80 & Forero Nuñez et al. (2015) \\
\hline 61.73 & 16.24 & 11.07 & 10.96 & Adjin-Tetteh et al. (2018) \\
\hline 68.47 & 10.81 & 10.29 & 10.43 & Titiloye et al. (2013) \\
\hline 70.40 & 10.90 & 14.00 & 16.70 & Kilama et al. (2019) \\
\hline 49.90 & 13.50 & 16.10 & 20.50 & Syamsiro et al. (2012) \\
\hline 64.19 & 15.31 & 10.10 & 10.40 & Asiedu et al. (2019) \\
\hline 58.75 & 06.99 & 14.43 & 19.83 & Chan and Choo (2013) \\
\hline 92.60 & 07.39 & - & - & Antwi et al. (2019) \\
\hline- & 07.40 & 11.04 & - & Nazir et al. (2016) \\
\hline
\end{tabular}

Knowing of the moisture content of a biomass is crucial for the choice of the energy conversion method available for processing this biomass. According to Tsai et al. (2017), moisture content has a direct impact on the calorific value of a biofuel. The values obtained during various studies were all over $10 \%$. Thus, the residue would be better suited for biochemical conversion than thermal conversion (Adjin-Tetteh et al. 2018). Further, moisture in the raw material can act as a binder (Adjin-Tetteh et al. 2018) and lubricant by improving the gelatinization of starch and facilitating the formation of van der Waals forces (Adjin-Tetteh et al. 2018) and the possible diffusion of water-soluble substances in the matrix of the raw material (Titiloye et al. 2013). The ash contents of the different samples were quite high, which reflected a higher level of inorganic substances that can act as catalysts for the whole thermal conversion process (Titiloye et al. 2013). Tables 2 and 3 present the lignocellulosic and mineralogical composition of $\mathrm{CPH}$ in different studies around the world. 
Table 2. Biochemical Composition of $\mathrm{CPH}$ in Previous Studies

\begin{tabular}{|c|c|c|c|c|}
\hline Lignin (\%) & Cellulose (\%) & Hemicellulose (\%) & Pectin (\%) & Reference \\
\hline 24.16 & 28.25 & 16.75 & - & Sandesh et al. (2020) \\
\hline 12.06 & 18.42 & 10.04 & - & Marsiglia et al. (2016) \\
\hline 14.70 & 35.40 & 37.00 & - & Daud et al. (2014) \\
\hline 33.96 & 30.41 & 11.97 & - & Titiloye et al. (2013) \\
\hline 14.00 to 28.00 & 19.70 to 26.10 & 8.70 to 12.80 & 06.00 to 12.60 & Lu et al. (2018) \\
\hline 18.19 & 23.04 & 38.08 & - & Asiedu et al. (2019) \\
\hline 14.60 to 26.38 & 24.24 to 35.00 & 8.72 to 11.00 & 6.10 to 9.20 & Vásquez et al. (2019) \\
\hline 34.82 & 44.69 & 11.15 & $10.10 \pm 0.3$ & Nazir et al. (2016) \\
\hline
\end{tabular}

An analysis of Table 1, Table 2, and Table 3 illustrates the rich lignocellulosic and chemical composition of $\mathrm{CPH}$, which could lead to its use as a potential substrate for anaerobic digestion (Rastegari et al. 2019) to produce bioactive compounds.

Table 3. Chemical Composition of $\mathrm{CPH}$ in Previous Studies

\begin{tabular}{|c|c|c|c|c|c|c|c|c|}
\hline $\begin{array}{c}\text { Phosph } \\
\text { orus } \\
(\mathrm{P})\end{array}$ & $\begin{array}{c}\text { Potassiu } \\
\mathrm{m}(\mathrm{K})\end{array}$ & $\begin{array}{c}\text { Calcium } \\
(\mathrm{Ca})\end{array}$ & $\begin{array}{c}\text { Magnesi } \\
\text { um }(\mathrm{Mg})\end{array}$ & $\begin{array}{c}\text { Iron } \\
(\mathrm{Fe})\end{array}$ & $\begin{array}{c}\text { Manganese } \\
(\mathrm{Mn})\end{array}$ & $\begin{array}{c}\text { Sodium } \\
(\mathrm{Na})\end{array}$ & $\begin{array}{c}\text { Zinc } \\
(\mathrm{Zn})\end{array}$ & Reference \\
\hline- & 2.768 & 0.254 & 0.111 & $\begin{array}{c}0.005 \\
8\end{array}$ & 0.036 & 0.0105 & 0.0397 & $\begin{array}{c}\text { Vásquez } \\
\text { et al. } \\
(2019)\end{array}$ \\
\hline- & 3.77 & 0.46 & 0.25 & 0.003 & - & 0.016 & - & $\begin{array}{c}\text { Gyedu- } \\
\text { Akoto et } \\
\text { al. (2015) }\end{array}$ \\
\hline 0.19 & 2.8 to 3.8 & $\begin{array}{c}0.25 \text { to } \\
0.46\end{array}$ & $\begin{array}{c}0.11 \text { to } \\
0.25\end{array}$ & $\begin{array}{c}0.003 \\
\text { to } \\
0.06\end{array}$ & - & $\begin{array}{c}0.01 \text { to } \\
0.02\end{array}$ & - & $\begin{array}{c}\text { Lu et al. } \\
(2018)\end{array}$ \\
\hline 0.39 & 3.22 & 0.30 & 0.00 & $\begin{array}{c}0.035 \\
124\end{array}$ & 0.005010 & 0.45 & $\begin{array}{c}0.0056 \\
23\end{array}$ & $\begin{array}{c}\text { Antwi } \text { et } \\
\text { al. (2019) }\end{array}$ \\
\hline 0.10 & 3.40 & 0.60 & 0.40 & - & - & 0.00 & - & $\begin{array}{c}\text { Djeke et } \\
\text { al. (2011) }\end{array}$ \\
\hline
\end{tabular}

These bioactive compounds have many applications, which include renewable energy, biopolymers, formulating plasticized composites, and acting as a fertilizer element (Djeke et al. 2011; Kouakou et al. 2018).

The disparities observed between the physico-chemical and biochemical compositions of the $\mathrm{CPH}$ could have been due to geographic factors, the location of the materials collected, the different methods of analysis, the variety of biomass, the differences in the solvents used, the different collection periods (Sandesh et al. 2020), and the different climatic and storage conditions (Titiloye et al. 2013), among other factors.

\section{Lignocellulosic Biomass Pretreatment}

Lignocellulosic biomass is a renewable material that can be converted into fermentable sugars and then converted into ethanol (Rezania et al. 2017). However, this convention is hampered by the recalcitrant nature of this plant biomass (Woiciechowski et al. 2020) due to the presence of lignin and the consequent difficulty of obtaining complete 
enzymatic hydrolysis has led to the implementation of different pretreatment strategies (Beukes and Pletschke 2010). Pretreatment aims to modify the properties of raw materials, to remove or dissolve lignin and hemicellulose, and to reduce the crystallinity of cellulose (Thamsee et al. 2019). It is performed to increase the surface accessible to hydrolytic enzymes (Wang et al. 2015). The pretreatment process further alters the microstructure, macrostructure, and chemical composition of lignocellulose to improve the efficiency of the hydrolysis of sugars (Chandra et al. 2015) to make them accessible to microbial degradation (An et al. 2015). The pretreatment process improves the efficiency of and stimulates sugar hydrolysis (Chandra et al. 2015). As the separation of carbohydrates from lignocellulose is a key step in the process, the choice of pretreatment strategy is crucial to facilitate the transformation of lignocellulosic biomass into products with high added value (Arevalo-Gallegos et al. 2017). The four pretreatment strategies are physical, chemical, physico-chemical, and biological.

In general, chemical and physicochemical pretreatments give good results. However, excessive use of chemicals could lead to serious environmental problems (Chen et al. 2017). The biological method consumes less energy and is less polluting than other methods, but it is expensive and time consuming, and enzyme activity in the decomposition of lignocellulose is low (Chen et al. 2017).

The following section discusses the pretreatment technologies commonly used in the recovery of lignocellulosic biomass in general and those applied to valorize $\mathrm{CPH}$ in particular.

\section{Pretreatment with acid solution}

Acid pretreatment is a highly effective chemical technique used to break down the lignocellulosic matrix by cleavage of the glucosidic bonds (Woiciechowski et al. 2020). Acid pretreatment mainly solubilizes hemicelluloses and part of the lignin (Woiciechowski et al. 2020). Inorganic acids ((sulfuric acid $\left(\mathrm{H}_{2} \mathrm{SO}_{4}\right)$, nitic acid $\left(\mathrm{HNO}_{3}\right)$, and phosphoric acid $\left(\mathrm{H}_{3} \mathrm{PO}_{4}\right)$ ) and organic ones (formic acetic and propionic acid) (Aslanzadeh et al. 2014) are generally used. However, most concentrated acids are highly toxic and corrosive, so the acid must be recovered, and the equipment used must be resistant to acid corrosion (Manzoor et al. 2013; Laurens et al. 2015; Chen et al. 2017). This results in high operational and maintenance costs, and the process destroys hemicellulosic sugars and transforms them into toxic compounds, such as acetic acid, furfural, and 5hydroxymethylfurfural (5-HMF), which inhibits microbial growth (Woiciechowski et al. 2020). However, the conversion rate to sugar is higher than pretreatments that use hydrochloric acid, phosphoric acid, or nitric acid (Mosier et al. 2005; Sandesh et al. 2020). The optimization of biogas production by applying acid $\left(\mathrm{H}_{2} \mathrm{SO}_{4}\right)$ pretreatments to $\mathrm{CPH}$ has been achieved (Ward-Doria et al. 2016). Likewise, cocoa pod husks have been used to release reducing sugars using autoclave-assisted hydrochloric acid hydrolysis to obtain reducing sugars (Shet et al. 2019). The concentration of hydrochloric acid $(\mathrm{HCl})$ and the duration of the autoclave were used to optimize the hydrolysis process. Under optimized conditions $21.11 \mathrm{~g} / \mathrm{L}$ of reducing sugar were released (Shet et al. 2019). Otherwise, a study by Dahunsi et al. (2019a) showed that cocoa pods husks could produce up to $71 \%$ biogas via the mono-fermentation of $\mathrm{CPH}$ pretreated with sulfuric acid $\left(\mathrm{H}_{2} \mathrm{SO}_{4}\right)$ and alkaline hydrogen peroxide $\left(\mathrm{H}_{2} \mathrm{O}_{2}\right)$. Additionally, xylitol has been produced from xylose from cocoa pod husks using sulfuric acid pretreatment, optimized by the response surface methodology (Santana et al. 2018). Xylitol was obtained at concentrations of 11.34 g.L. ${ }^{-1}$, corresponding to a yield $(\mathrm{Y} \mathrm{p} / \mathrm{s})$ of $0.52 \mathrm{~g}^{\mathrm{g}} \mathrm{g}^{-1}$ with a fermentation efficiency of $56.6 \%$. 


\section{Alkaline pretreatment}

Alkaline pretreatment is an economical process that is carried out by soaking a ground biomass in a basic solution at relatively low temperatures and pressures (Beukes and Pletschke 2010; Umagiliyage et al. 2015). It is an interesting technology, in which the formation of few fermentation inhibitors occurs (Beukes and Pletschke 2010). This pretreatment increases the surface area exposed to enzymatic hydrolysis and the accessibility of cellulose by removing the acetyl and uronic acid substituents associated with hemicelluloses (Umagiliyage et al. 2015). The alkaline solutions of sodium hydroxide $(\mathrm{NaOH})$, potassium hydroxide $(\mathrm{KOH})$, calcium hydroxide $\left(\mathrm{Ca}(\mathrm{OH})_{2}\right.$, and ammonium hydroxide $\left(\mathrm{NH}_{4} \mathrm{OH}\right)$ are suitable for the pretreatment of lignocellulose (Mirmohamadsadeghi et al. 2016; Saratale et al. 2016). For example, $\mathrm{Ca}(\mathrm{OH})_{2}$ can remove the acetyl group from hemicellulose to increase the digestibility of cellulose and reduce the steric hindrance of enzymes (Chen et al. 2017). Then, $\mathrm{Ca}(\mathrm{OH})_{2}$ can increase the crystallinity index by eliminating amorphous substances (Chen et al. 2017). The optimal pretreatment conditions $\left(\mathrm{Ca}(\mathrm{OH})_{2}\right.$ and $\left.\mathrm{NaOH}\right)$ for sweet sorghum bagasse have been determined (Umagiliyage et al. 2015). Expected yields of $85.6 \%$ biomass to biofuel conversion and $35.5 \%$ lignin removal can be achieved.

Several upgrading processes that employ $\mathrm{CPH}$ as recoverable biomass have integrated alkaline pretreatment and led to the production of biogas from the anaerobic codigestion of $\mathrm{CPH}$ and poultry manure after pretreatment with sulfuric acid and hydrogen peroxide (Dahunsi et al. 2019b). The use of alkaline hydrogen peroxide resulted in solubilization of up to $81 \%$ of the lignin from the $\mathrm{CPH}$.

The optimization of biogas production by applying acid $\left(\mathrm{H}_{2} \mathrm{SO}_{4}\right)$ and alkaline $(\mathrm{NaOH})$ pretreatments to $\mathrm{CPH}$ has been achieved (Ward-Doria et al. 2016), and the alkaline pretreatment gave the best result of up to $43.8 \%$ delignification. The effect of reagent type (sodium hydroxide $(\mathrm{NaOH})$, alkaline peroxide $\left(\mathrm{H}_{2} \mathrm{O}_{2}\right)$, and sulfuric acid $\left(\mathrm{H}_{2} \mathrm{SO}_{4}\right)$ ) was also evaluated on the delignification of $\mathrm{CPH}$ using response surface methodology (Nazir et al. 2016). The alkaline pretreatment still had the best results independent of reagent type.

\section{Steam-explosion pretreatment}

The steam-explosion process is among the most widely used physico-chemical pretreatment processes. This process occurs when water vapor is subjected to a high temperature for a few seconds to several minutes and then rapidly expelled from the reactor (Chen et al. 2017). The flow of vapor and liquid material cools rapidly due to the reduced pressure (Chen and Liu 2015). The main mechanism of the process is the high-pressure vapor in the fibers that causes the mechanical breakdown of the fiber. It is an inexpensive option for the pretreatment of agricultural residues, and it has a considerably reduced environmental impact (López-Linares et al. 2015). It has a lower environmental impact, lower requirements in terms of reaction conditions and cost, and fewer risks linked to chemical reagents and complete recovery of sugar than other methods. Further, this pretreatment leads to the formation of degradation products of sugars, such as acetic acid formed by the self-hydrolysis of acetyl groups at elevated temperatures or many phenolic compounds (Chen et al. 2017). This could justify why no valuation study of CPH has mentioned the application of steam-explosion pretreatment.

\section{Explosion of ammonia-pretreated fibers}

The explosion-of-ammonia-fiber (AFEX) pretreatment is a combination of steamexplosion pretreatment and alkaline pretreatment in anhydrous ammonia at high 
temperature $\left(90{ }^{\circ} \mathrm{C}\right.$ to $100{ }^{\circ} \mathrm{C}$ ) and high pressure (1 MPa to 5.2 MPa) (Chen et al. 2017). After a rapid release of pressure, the ammonia is vaporized, which leads to a sudden change in temperature. As a result, the structure of the biomass is severely damaged, thus exposing the cellulose surface to increased enzymatic hydrolysis (Chen et al. 2017). The main advantage of AFEX pretreatment is the absence of substances that inhibit microbial fermentation. This process also produces a residue of ammonium salt that can serve as a nutrient for microbial fermentation (Chen et al. 2017). Thus, the resulting hydrolyzate after pretreatment can be directly used without further specific treatment. Under these conditions, AFEX is therefore suitable for the pretreatment of agricultural waste and herbaceous plants that contain a high content of cellulose (Wyman et al. 2005). However, the ammonia used must be recycled due to its high cost and volatility (Taherzadeh and Karimi 2008). However, to our knowledge, no study in the literature has yet explored the use of pre-blast pretreatment of cocoa pods husks fibers with ammonia.

\section{$\mathrm{CO}_{2}$-explosion pretreatment}

The $\mathrm{CO}_{2}$-explosion pretreatment combines steam explosion and the addition of $\mathrm{CO}_{2}$ to form carbonic acid, the presence of which greatly improves the efficiency of hemicellulosic hydrolysis (Chen et al. 2017). This process has enormous advantages, including the absence of inhibitors during subsequent fermentation; further, it is non-toxic, non-flammable, and cost-effective (Chen et al. 2017). In addition, the surface of the resulting substrate is easily accessible to subsequent enzymatic attack. A Box-Behnken design was applied to supercritical $\mathrm{CO}_{2}$ extraction to develop an appropriate ecological process to obtain a soluble fraction rich in phenolic compounds from CPH (Alemawor et al. 2009).

\section{Microwave pretreatment}

Microwave technology makes cellulose more responsive and improves the accessibility and adaptability of the lignocellulosic feedstock to enzymes (Chen et al. 2017). It is an energy efficient technology that is applicable in chemical reactions (Chen $e t$ al. 2017). Several studies have focused on microwave pretreatment of fibrous raw materials (Manzoor et al. 2013; Lo et al. 2015). Microwave pretreatment allows a subsequent increase in enzyme activity (Chen et al. 2017), but it requires a high investment. Microwave-assisted pretreatment optimization of $\mathrm{CPH}$ using sulfuric acid $\left(\mathrm{H}_{2} \mathrm{SO}_{4}\right)$ was also performed by comparing the efficiency of the response surface methodology to that of the network of artificial neurons to produce bioethanol (Shet et al. 2018b), and a maximum of $9.10 \mathrm{~g} / \mathrm{L}$ of sugars was released.

\section{Biological method}

The degradation of lignin is facilitated by biological pretreatment, as it can generate enzymes that break down lignin during the process. Biological pretreatment usually uses wood-rotting fungi (Chen et al. 2017). Different lignocellulosic biomasses have been biologically pretreated using fungi, such as white rot, Ceriporiopsis subvermispora, Pleurotus ostreaus, Ceriporia lacerata, Cyathus stercolerus, Pycnoporus cinnarbarinus, and Phanerochaete chrysosporium, on different lignocellulosic biomasses (Chen et al. 2017). Thus, the biological pretreatment of CPH has been carried out via the use of fungal species chrysosporium of the genus Phanerochaete (Laconi and Jayanegara 2015), and this species has shown its effectiveness in improving the nutritional value of CPH. Similarly, Pleurotus ostreatus (Alemawor et al. 2009) reduced cellulose, hemicellulose, and lignin 
content by $6 \mathrm{wt} \%, 3 \mathrm{wt} \%$, and $6 \mathrm{wt} \%$, respectively, with manganese ion supplementation $\left(\mathrm{Mn}^{+2}\right)$. These results show that the Pleurotus species has promising cellulolytic and hemicellulolytic activity on CPH (Alemawor et al. 2009). Table 4 summarizes past work on the pretreatment of $\mathrm{CPH}$.

Table 4. Main Pretreatment Strategies Applied to Cocoa Pod Husk in Previous Studies

\begin{tabular}{|c|c|c|c|}
\hline Pretreatment Method & Intended Use & Yield & Reference \\
\hline Chemical $\left(\mathrm{Na}_{2} \mathrm{CO}_{3}\right)$ & $\begin{array}{c}\text { Optimization (reducing } \\
\text { sugars) }\end{array}$ & $0.94 \mathrm{~g} / \mathrm{L}$ & Shet et al. (2016) \\
\hline $\begin{array}{c}\text { Chemical }\left(\mathrm{H}_{2} \mathrm{SO}_{4},\right. \\
\mathrm{NaOH})\end{array}$ & $\begin{array}{c}\text { Optimization } \\
\text { (delignification) }\end{array}$ & $74.48 \%$ & Nazir et al. (2016) \\
\hline $\begin{array}{c}\text { Chemical }\left(\mathrm{H}_{2} \mathrm{SO}_{4},\right. \\
\mathrm{NaOH})\end{array}$ & Biomethane production & $0.247 \mathrm{~m}^{3} \mathrm{CH}_{4} / \mathrm{kg} \mathrm{VS}$ & $\begin{array}{l}\text { Ward-Doria et al. } \\
(2016)\end{array}$ \\
\hline $\begin{array}{c}\text { Chemical }(\mathrm{NaOH}), \\
\text { sonification }\end{array}$ & Microcrystalline cellulose & $286 \mathrm{~nm}$ & Jimat et al. (2016) \\
\hline Chemical $\left(\mathrm{H}_{2} \mathrm{SO}_{4}\right)$ & Bioethanol production & $2 \mathrm{~g} / \mathrm{L}$ & Shet et al. (2018a) \\
\hline $\begin{array}{c}\text { Chemical }\left(\mathrm{H}_{2} \mathrm{SO}_{4},\right. \\
\left.\mathrm{H}_{2} \mathrm{O}_{2}\right)\end{array}$ & Biogas production & $243.3 \pm 4.1 \mathrm{I}(\mathrm{N}) / \mathrm{kg}$ VS & $\begin{array}{c}\text { Dahunsi et al. } \\
(2019 a)\end{array}$ \\
\hline Mechanical (grinding) & Methane production & $22 \%$ & Dahunsi (2019) \\
\hline Hydrothermal & Biogas production & $526.38 \mathrm{I}(\mathrm{N}) / \mathrm{kg} \mathrm{VS}$ & Antwi et al. (2019) \\
\hline $\begin{array}{c}\text { Biological } \\
\text { (Phanerochaete } \\
\text { chrysosporium) }\end{array}$ & $\begin{array}{l}\text { Feed production for } \\
\text { ruminants }\end{array}$ & $\begin{array}{l}\text { Increased digestibility } \\
(28.5 \%)\end{array}$ & $\begin{array}{c}\text { Laconi and } \\
\text { Jayanegara (2015) }\end{array}$ \\
\hline $\begin{array}{c}\text { Biological (Pleurotus } \\
\text { ostreatus) }\end{array}$ & $\begin{array}{l}\text { Improving nutritional } \\
\text { status }\end{array}$ & $\begin{array}{l}\text { 17\% Reduction (crude } \\
\text { fiber and lignin) }\end{array}$ & $\begin{array}{l}\text { Alemawor et al. } \\
\qquad(2009)\end{array}$ \\
\hline $\mathrm{CO}_{2}$ explosion & Phenolic compounds & $12.97 \mathrm{mg} \mathrm{GAE} / \mathrm{g}$ & $\begin{array}{l}\text { Valadez-Carmona } \\
\text { et al. (2018) }\end{array}$ \\
\hline
\end{tabular}

\section{Cocoa Pod Husk Conversion Processes}

Several conversion routes (physical, biochemical, and thermochemical) of biomass into products with high added value, such as biofuels and biochemicals, have been exploited (Tsai et al. 2017; Adjin-Tetteh et al. 2018). Volatile materials are suitable for combustion, gasification, and pyrolysis. As the volatility of a given material increases, the ignition speed of the resulting biofuel increases (Chan and Choo 2013). However, among thermochemical conversion technologies, pyrolysis has sizable advantages over other biomass and waste processing technologies (Adjin-Tetteh et al. 2018). Pyrolysis is the decomposition of matter under the influence of water vapor (Chen et al. 2017). During the pyrolysis process, cellulose decomposes rapidly when heated to above $300{ }^{\circ} \mathrm{C}$, which results in the release of gaseous products and the production of coke-like residues (Chen et al. 2017). In addition, other polysaccharide degradation products, such as furfural and aldehydes, can form in the presence of acid and limit microbial fermentation (Laser et al. 2002). This treatment is applied only when the biomass has a solids content less than $20 \%$, which results in high energy consumption and relatively low productivity (Laser et al. 2002). The high-value-added bio-oil it produces can compete with and potentially replace non-renewable fossil fuels (Adjin-Tetteh et al. 2018).

Cocoa pod husk has been shown to be an excellent raw material for pyrolysis reactions (Adjin-Tetteh et al. 2018). Moreover, CPH contains a mixture of cellulose, 
hemicellulose, lignin, pectin, and crude fibers in large proportions. Therefore, it is a potential source of biomass substrates for biochemical production (Adjin-Tetteh et al. 2018). Indeed, a study on the technical-economic evaluation of five lignocellulosic biomass-treatment technologies (Maleka 2016) concluded that the two most effective treatment technologies for the recovery of cocoa pod husks are hydrothermal carbonization and anaerobic fermentation (Maleka 2016). Others studies have used $\mathrm{CPH}$ as a renewable energy source and analyzed its characteristics in a combustion chamber (Syamsiro et al. 2012). The crushed bales were charred at $400{ }^{\circ} \mathrm{C}$ for $2 \mathrm{~h}$, which resulted in a higher calorific rate $\left(17 \mathrm{M} \times \mathrm{Kg}^{-1}\right)$ with a high ash content.

Table 5. Main Conversion Processes Applied to Cocoa Pod Husk

\begin{tabular}{|c|c|c|c|}
\hline \multicolumn{2}{|c|}{ Conversion Pathways } & Applications & Reference \\
\hline \multirow{8}{*}{ Thermochemical } & Hydrothermal carbonization & $\begin{array}{c}\text { - Phenolic } \\
\text { compounds and } \\
\text { sugars } \\
\text { - Bio-oil } \\
\text { production } \\
\text { - Briquette } \\
\text { production }\end{array}$ & $\begin{array}{c}\text { Hernández- } \\
\text { Hernández et al. } \\
(2019) \\
\text { Ogunjobi and } \\
\text { Lajide (2015) } \\
\text { Ofori and Akoto } \\
(2020)\end{array}$ \\
\hline & Direct Combustion & $\begin{array}{l}\text { - Heat energy } \\
\text { production }\end{array}$ & $\begin{array}{c}\text { Syamsiro et al. } \\
(2012)\end{array}$ \\
\hline & Gasification & $\begin{array}{l}\text { - Energy } \\
\text { production }\end{array}$ & $\begin{array}{c}\text { Martínez-Ángel et } \\
\text { al. (2015) }\end{array}$ \\
\hline & \multirow{5}{*}{ Pyrolysis } & $\begin{array}{l}\text { - Biochar } \\
\text { production }\end{array}$ & Tsai et al. (2017) \\
\hline & & $\begin{array}{l}\text { - Amoxicillin and } \\
\text { ibuprofen } \\
\text { elimination }\end{array}$ & Tovar et al. (2018) \\
\hline & & - Bio-oil & $\begin{array}{c}\text { Adjin-Tetteh et al. } \\
\text { (2018) }\end{array}$ \\
\hline & & - Biofuel & $\begin{array}{c}\text { Akinola et al. } \\
(2018)\end{array}$ \\
\hline & & - Pyrolysis oil & $\begin{array}{l}\text { Mansur et al. } \\
(2014)\end{array}$ \\
\hline \multirow{7}{*}{ Biochemical } & \multirow{7}{*}{ Anaerobic Digestion } & $\begin{array}{c}\text { - Bio-oil and } \\
\text { biogas }\end{array}$ & $\begin{array}{c}\text { Chan and Choo } \\
\text { (2013) }\end{array}$ \\
\hline & & $\begin{array}{l}\text { - Energy } \\
\text { production }\end{array}$ & $\begin{array}{l}\text { Acosta et al. } \\
(2018)\end{array}$ \\
\hline & & $\begin{array}{l}\text { - Biogas } \\
\text { production }\end{array}$ & Antwi et al. (2019) \\
\hline & & $\begin{array}{l}\text { - Biogas } \\
\text { production }\end{array}$ & $\begin{array}{c}\text { Mancini et al. } \\
(2016)\end{array}$ \\
\hline & & $\begin{array}{l}\text { - Biogas } \\
\text { production }\end{array}$ & $\begin{array}{l}\text { Ward-Doria et al. } \\
(2016)\end{array}$ \\
\hline & & $\begin{array}{l}\text { - Biobutanol } \\
\text { production }\end{array}$ & $\begin{array}{c}\text { Sandesh et al. } \\
(2020)\end{array}$ \\
\hline & & - Biogas & $\begin{array}{l}\text { Dahunsi et al. } \\
\text { (2019b) }\end{array}$ \\
\hline
\end{tabular}

Ofori-Boateng and Lee (2013) evaluated CPH as a solid base catalyst for the transesterification of soy oil into biodiesel. According to their results, $\mathrm{CPH}$ potash could be a viable basic catalyst, generate high yields in biodiesel production, and offer engine 
performance similar to that of petroleum diesel. Table 5 summarizes the routes for converting $\mathrm{CPH}$ into bioproducts for valorization.

Anaerobic digestion is a natural process that occurs in an oxygen-free environment (Morales et al. 2019). During this process, biodegradable materials are converted into biogas using microorganisms (Morales et al. 2019). Several studies have shown the application of this process to convert CPH to produce biogas (Ward-Doria et al. 2016) after alkaline and acid pretreatment. In addition, the use of response surface methodology to assess the effect of hydrothermal pretreatment on biogas yield and optimal pretreatment conditions was examined by Antwi et al. (2019). In addition, Acosta et al. (2018) demonstrated the potential of cocoa waste as a renewable energy source in rural areas via anaerobic digestion.

Artificial neural networks have also been used to predict biodigester production using CPH as biomass at the University of Piura pilot plant in Peru (Morales et al. 2019). Further, the co-digestion of biomass residues to produce fuel has also been presented in recent studies, in which biogas was produced from $\mathrm{CPH}$ and poultry manure (Dahunsi et al. 2019b).

Cocoa pod husks have also been explored commercially and industrially through patent research and development to take advantage of their rich chemical and biochemical compositions (Vásquez et al. 2019). Previous studies have shown the potential applications of $\mathrm{CPH}$ (Vásquez et al. 2019). Therefore, $\mathrm{CPH}$ is widely used because it allows the implementation of new products with high added value by using new processes that are applicable to the food, cosmetic, pharmaceutical, and biomaterial industries (Vásquez et al. 2019). Table 6 presents a brief list of product patents related to the use of $\mathrm{CPH}$.

Table 6. Patents Related to the Use of Cocoa Pod Husk

\begin{tabular}{|c|c|c|}
\hline Patent Number & Use & Reference \\
\hline US4206245A & Preparation of small animal feed from $\mathrm{CPH}$ & $\begin{array}{l}\text { Drevici and } \\
\text { Drevici (1980) }\end{array}$ \\
\hline WO2014042517A2 & Biofertilizer & $\begin{array}{l}\text { Rahman et al. } \\
\quad(2014)\end{array}$ \\
\hline WO2015018957A1 & $\begin{array}{l}\text { Method for the synthesis of active carbon monoliths } \\
\text { from cacao skin }\end{array}$ & Monge (2015) \\
\hline ES2539845B1 & $\begin{array}{c}\text { Procedure and synthesis of activated carbon } \\
\text { monoliths from cocoa pod husk }\end{array}$ & Monge (2016) \\
\hline EP3613297A1 & $\begin{array}{l}\text { Procedure for extracting pectin from } \mathrm{CPH} \text { and } \\
\text { application in the food, pharmaceutical and personal } \\
\text { care industries }\end{array}$ & Bernaert (2020) \\
\hline WO2020038906A1 & $\begin{array}{c}\text { Cacao pod husk powder, method of its preparation } \\
\text { and its use in food, pharmaceutical and cosmetic } \\
\text { compositions }\end{array}$ & $\begin{array}{l}\text { Bernaert and } \\
\text { Kopp }(2020 a)\end{array}$ \\
\hline WO2020038905A1 & $\begin{array}{c}\text { Process to extract components of cacao pod husks } \\
\text { and to utilize cacao fruit soluble extract obtained } \\
\text { thereof and its applications }\end{array}$ & $\begin{array}{l}\text { Bernaert and } \\
\text { Kopp (2020b) }\end{array}$ \\
\hline
\end{tabular}

In the following sections, the current state of the valorization of $\mathrm{CPH}$ and its potential applications are described.

Valorization of Cocoa Pod Husk Residues into High Value-added Products Soap making 
Consumers are becoming more conscious of natural and organic personal care products, as certain synthetic chemicals have been shown to be harmful to humans (GyeduAkoto et al. 2015). Cocoa pods husks, which make up $60 \%$ to $75 \%$ of the cocoa fruit, contain a large amount of minerals, the most abundant of which is potassium $(\mathrm{K})$; thus, this residue is an inexpensive source of caustic potash (Gyedu-Akoto et al. 2015). Cocoa pod husks could therefore be used for soap making in West African countries (Gyedu-Akoto et al. 2015). Indeed, each tonne of pods would produce approximately $6 \mathrm{~kg}$ of potash (GyeduAkoto et al. 2015). After filtering and concentration, this potash could be used for the saponification of oil to produce soap (Onyegbado et al. 2002). Some soaps derived from $\mathrm{CPH}$ have been successfully produced in a pilot plant in Ghana and in several African countries (Gyedu-Akoto et al. 2015). Potash-based soaps from CPH have higher solubility, consistency, cleaning power, and foaming capacity than chemical $\mathrm{KOH}$-based soaps (Taiwo and Osinowo 2001). Appropriate use as a raw material for making commercial soap could also generate additional income for farmers in cocoa-producing countries.

\section{Extracting bioactive compounds}

The increasingly strong demand for crude oil reserves and the intensification of the effect of greenhouse gases are prompting researchers to implement chemical production processes based on biomass instead of petrochemical processes (Mansur et al. 2014). Lignocellulosic biomass is an accessible, renewable, and abundant resource. It is considered the only raw material for the sustainable production of platform chemicals (Mansur et al. 2014).

Lignocellulosic biomass has been increasingly used for the production of platform chemicals (Mansur et al. 2014). Among these chemicals with high added value, pectin, which is a natural food hydrocolloid, has use in the food industry for its gelling properties (Priyangini et al. 2018). Cocoa pod husks, which are a residual and abundant biomass, are part of the crop waste that can be used for this purpose (Vriesmann et al. 2011a; Mansur et al. 2014). The composition of $\mathrm{CPH}$, the main waste product of cocoa production, and some of the characteristics of their hot-water-soluble pectins have been determined (Vriesmann et al. 2011a). The authors have shown that water, a natural extraction agent, could be used to obtain pectins more effectively than a conventional extraction based on mineral acids (Vriesmann et al. 2011a) because there was no pectin formation. This study demonstrates that cocoa pod husks have a high content of dietary fiber and phenolic compounds (Vriesmann et al. 2011a), which makes them a potential source of natural compounds with exceptional nutritional and functional qualities. The variables that influence the nitric acid extraction of pectins from cocoa pods husks were examined by Vriesmann et al. (2011b). The authors used a central-composite design based on the response surface methodology with three factors, which were hydrogen potential $(\mathrm{pH})$, extraction temperature $(T)$, and extraction time $(t)$ (Vriesmann et al. 2011b). Cocoa pod husks were used by Priyangini et al. (2018) as a source for extracting pectin by treatment with sweet acid (ascorbic acid). A comprehensive factorial design was applied by these authors to examine the independent variables that affect yield and uronic acid content (Priyangini et al. 2018). A Box-Behnken design was used to optimize the supercritical $\mathrm{CO}_{2}\left(\mathrm{SC}-\mathrm{CO}_{2}\right)$ extraction to develop an appropriate ecological process aimed to obtain an extract enriched in phenolic compounds from the pods of CPH (Valadez-Carmona et al. 2018). This process made it possible to reduce the extraction times (with low yield), to improve the quality of the extracts, and to reduce the loss of volatile compounds (Valadez-Carmona et al. 2018). In addition, it avoided the degradation of bio-compounds due to heat and reduced the high solvent 
consumption (Valadez-Carmona et al. 2018). The results of the study showed that supercritical fluid extraction could be used as a technique to obtain an extract enriched in phenolic compounds from CPH (Valadez-Carmona et al. 2018). Abdul Karim et al. (2014a) performed a study to determine the total phenolic and flavonoid content of CPH compared to cocoa bean shell. They determined that $\mathrm{CPH}$ and cocoa bean shell have antioxidant activity with promising amounts of total phenolic and flavonoid content (Abdul Karim et al. 2014b).

Therefore, $\mathrm{CPH}$ are agricultural residues of great importance and can be used as basic raw materials for the synthesis of useful products in cosmetics (Abdul Karim et al. 2016). The highly active and stable crosslinked enzyme aggregate (CLEA)-lipase from the pod husks has been tested for its hydrolytic activity and successfully characterized under optimal conditions (Khanahmadi et al. 2015). The core-composite design based on response surface methodology was used to achieve the optimal conditions for pectin extraction (Vriesmann and de Oliveira Petkowicz 2017). Pectin was extracted from cocoa pod husks using aqueous nitric acid as an extractant and boiling water (Vriesmann and de Oliveira Petkowicz 2017). This study showed that pectin from the CPH could form low $\mathrm{pH}$ gels with reduced water activity (Vriesmann and de Oliveira Petkowicz 2017). This discovery encourages further work on the application of pectins obtained in acidic products from CPH (Vriesmann and de Oliveira Petkowicz 2017). Mansur et al. (2014) treated CPH by pyrolysis to produce a pyrolysis oil that contained several chemical compounds, such as ketones, carboxylic acids, aldehydes, furans, heterocyclic aromatics, alkylbenzenes, phenols, and benzenediols (Vriesmann and de Oliveira Petkowicz 2017). The authors obtained an improved pyrolysis oil compared to that obtained from iron oxide catalysts.

Hernández-Hernández et al. (2019) have implemented industrial technologies, such as heat treatment between $50{ }^{\circ} \mathrm{C}$ and $200{ }^{\circ} \mathrm{C}$, which are currently used for the use and recovery of other lignocellulosic by-products. This allowed the extraction of bioactive compounds from CPH of several Mexican genotypes (Hernández-Hernández et al. 2018). Hydrothermal treatments at $150{ }^{\circ} \mathrm{C}$ or higher increased the solubilization of bioactive compounds and the antioxidant activity of the liquid phase (Hernández-Hernández et al. 2018). Treatment at $170{ }^{\circ} \mathrm{C}$ with water for 30 min was the most effective temperature for extracting both phenolics and sugars (Hernández-Hernández et al. 2018). However, 200 ${ }^{\circ} \mathrm{C}$ for $5 \mathrm{~min}$ was the best temperature for extracting theobromine and catechin (HernándezHernández et al. 2018).

Cocoa pod husk oil was studied by Adewole et al. (2015) to reveal the various compounds that it contained. Essential fatty acids and other organic compounds were revealed via a mass spectrophotometer coupled with gas chromatography. Further, low molecular weight carboxylic acids with a high yield were obtained by Asiedu et al. (2019) via an oxidation method catalyzed by two catalysts supported by metals that used $\mathrm{CPH}$ as the renewable material. The profiles of the concentration-time curves enabled the authors to model the kinetics and use the results to develop a new industrial operating technique, namely the concept of accessible region (AR) (Asiedu et al. 2019). This technique made it possible to minimize the volume of the reactors (thereby of the mass of catalyst) and to maximize the yield using a geometric optimization approach. In addition, Uy et al. (2019) found that $\mathrm{CPH}$ could be effectively converted to furfural. The authors also noted that a relatively high furfural yield (460.7 ppm) was achieved using an experimental BoxBehnken model to obtain the optimal conditions for the extraction of crude furfural by acid catalysis (Uy et al. 2019). 
The phytochemicals of CPH have been extracted (Rachmawaty et al. 2018). Their phenolic content and the bioactivity of a $\mathrm{CPH}$ extract against the pathogenic fungus Fusarium oxysporum were tested. Antifungal tests via the agar diffusion method revealed that an extract of $\mathrm{CPH}$ with acetone was capable of inhibiting the growth of Fusarium oxysporum (pathogen of the fungus on tomatoes) (Rachmawaty et al. 2018).

\section{Organic composts}

Depletion of fertile soils due to lack of nutrients is a concern in tropical regions (Fidelis and Rao 2017). Composting can potentially recycle waste to conserve natural resources. The high mineral content of cocoa pod husks $(\mathrm{CPH})$ or cocoa pod biomass $(\mathrm{CPB})$, mainly in potassium $(\mathrm{K})$, calcium $(\mathrm{Ca})$, and phosphorus $(\mathrm{P})$, suggests a potential to partially replace conventional fertilizers. Cocoa pod husks have been used as an organic amendment to fertilize degraded and ferralitic soils in the Oumé cocoa zone in Ivory Coast (Djeke et al. 2011). Cocoa pod husks are a source of organic matter that can improve the chemical parameters of soil and, under certain conditions, they could be used to fertilize degraded ferralitic soils in the Oumé region. The sorption and desorption of phosphate-P, ammoniacal nitrogen, and nitrate- $\mathrm{N}$ in biochars from cocoa pods husks and maize cobs were studied by Hale et al. (2013). They showed that biochar can slowly add and release essential nutrients to the soil to improve soil properties.

Another study by Munongo et al. (2017) produced compost manure and biochar from cocoa pods husks. Similarly, Ibiremo and Akanbi (2015) evaluated the effect of using a biochar enriched with different formulations of NPK fertilizers (solids and liquids) on $\mathrm{CPH}$ on the absorption of nutrients by kola seedlings and soil properties. Biochar and compost have been found to be alkaline in nature, which makes them suitable as a soil amendment, especially in acidic tropical soils.

The compost potential of CPH was evaluated by Doungous et al. (2018) as a soil conditioner to reduce the severity of black pod rot and consequently promote plant growth. Their results showed that the compost application increased soil $\mathrm{pH}$ and majority of the essential elements but decreased $\mathrm{Al}$ content, which is toxic to cocoa growth in acidic soils (Doungous et al. 2018). Further, Fidelis and Rao (2017) examined the possibility of producing nutrient-enriched compost from $\mathrm{CPH}$ that was infested with parasites with chemical amendments. When composted with superphosphate and poultry manure, CPH have produced good quality composts (Fidelis and Rao 2017). Such environmentally friendly applications could potentially reduce the use of expensive NPK fertilizers (Lu et al. 2018).

\section{Activated carbon precursor}

In general, 10 tonnes of $\mathrm{CPH}$ are yielded in the production of 1 tonne of dry beans (Pua et al. 2013). Based on its lignocellulosic content (Tsai and Huang 2018) and its abundant quantity, CPH appears to be an excellent precursor of activated carbon (AC). In fact, CHP, which is abundantly produced in certain African and Asian countries, has been tested as a precursor of $\mathrm{AC}$ to give it added value and avoid serious environmental problems linked to its presence in production fields.

Several works have mentioned its use. According to Cruz et al. (2012) CPH contains three chemical activating agents $\left(\mathrm{K}_{2} \mathrm{CO}_{3}, \mathrm{KOH}\right.$, and $\left.\mathrm{ZnCl}_{2}\right)$ that allow activated carbon to be obtained from them. The results obtained revealed that $\mathrm{CPH}$ can be used to produce AC by chemical activation (Cruz et al. 2012). In Nigeria, CPH have been used to adsorb heavy metals ( $\mathrm{Pb}$ and $\mathrm{Cu}$ ) from effluent water (Odubiyi et al. 2012). The resulting 
products were tested to adsorb heavy metals in effluent water at variable $\mathrm{pH}$ levels, dosages, and contact times. The effects of physical activation by carbon dioxide $\left(\mathrm{CO}_{2}\right)$ on the porosity and surface functional groups of AC prepared from the cocoa pod husks were evaluated (Ahmad et al. 2013b). In addition, the effects of acid leaching from CPH have been reported (Ahmad et al. 2013a). The study focused on porosity and surface functional groups (Ahmad et al. 2013a). Cocoa pod husks have also been used as an adsorbent to remove methylene blue (MB) from aqueous solutions (Pua et al. 2013). Pereira et al. (2014) conducted a study on the recovery of two agricultural residues. Their work aimed to prepare $\mathrm{AC}$ from $\mathrm{CPH}$ and siriguela seeds and to assess the adsorption of whey proteins (Bovine Serum Albumin (BSA)) and $\alpha$-bactalbumin) on the AC produced. Moreover, AC was synthesized and then characterized at low temperature from $\mathrm{CPH}$ that were modified with zinc chloride $\left(\mathrm{ZnCl}_{2}\right)$ to eliminate amoxicillin (Tejada et al. 2017). The biomass was characterized by elemental analysis, and the AC obtained was analyzed by scanning electron microscopy (SEM) and X-ray diffraction (XRD), followed by Brunauer-EmmettTeller (BET) surface analysis $\left(\mathrm{S}_{\mathrm{BET}}\right)$ to determine its chemical composition and its morphological and structural characteristics. The proximal analysis performed on the biomass $(\mathrm{CPH})$ showed a high carbon content, which makes it a suitable raw material for AC synthesis. In addition, Tsai et al. (2017) focused on the thermochemical characterization of biochar on $\mathrm{CPH}$ prepared at low pyrolysis temperature.

The results obtained by Tsai et al. (2017) highlighted the thermochemical characteristics of $\mathrm{CPH}$ to provide basic information on the thermochemical properties of $\mathrm{CPH}$-based biochars. The results of the thermochemical characterization, which included analyses of the calorific value and mineral components of $\mathrm{CPH}$, showed the presence of a percentage of volatile matter and a calorific value greater than $17.8 \mathrm{MJ} / \mathrm{kg}$, but there was a high $\mathrm{K}$ content in the ash (4.03 wt\%) (Tsai et al. 2017). Cocoa residues were also used by Tovar et al. (2018) to produce AC at low pyrolysis temperature. The authors prepared and characterized the biochar by SEM analysis (Tovar et al. 2018). They determined the chemical composition of the $\mathrm{CPH}$ and evaluated its use as a precursor of AC to eliminate amoxicillin and ibuprofen (Tovar et al. 2018). Another study proposed a strategy to modify the chemical properties of CPH to provide additional value (Fioresi et al. 2017). The authors stated that the grafting of aryl diazonium salt on $\mathrm{CPH}$ is spontaneous (Fioresi et al. 2017). They also elucidated that lignin was mainly involved in the immobilization of the phenolic layer (Fioresi et al. 2017). A study by Tsai and Huang (2018) improved the adsorption capacity of $\mathrm{AC}$ from ground $\mathrm{CPH}$, and the authors reused the solution as a liquid fertilizer after acid leaching. The effectiveness of pyrolysis techniques for the heat treatment of $\mathrm{CPH}$ has been demonstrated from the thermochemical conversion and characterization of CPH (Adjin-Tetteh et al. 2018; Tsai et al. 2020). The authors used rapid pyrolysis technologies that had notable advantages over other biomass- and wastetreatment technologies.

\section{Raw material for catalyst synthesis}

Biodiesel production is typically achieved through the process of transesterification (Abdullah et al. 2017). Indeed, this process is one of the simplest and most beneficial for producing biodiesel (Abdullah et al. 2017). It is catalyzed by a suitable heterogeneous or homogeneous catalyst (Abdullah et al. 2017). The use of lipases as a transesterification catalyst in reactions involving enzymes can be an excellent alternative to the production of environmentally friendly biodiesel (Khanahmadi et al. 2016). In this context, the transesterification of Jatropha curcas oil was enhanced using the enzyme aggregate- 
crosslinked lipase (CLEA) that was extracted from CPH (Khanahmadi et al. 2016). Further, it has been shown that it is possible to produce heterogeneous green basic catalysts from CPH to sustainably produce biodiesel (Ofori-Boateng and Lee 2013).

This type of catalyst offers several advantages, in that it is renewable, non-toxic, and reusable (Abdullah et al. 2017). In addition, it has high catalytic activity, stability in acidic and basic conditions, and high tolerance to water (Abdullah et al. 2017). Abdullah et al. (2017) examined the development of a heterogeneous base and an acid catalyst derived from biomass to produce biodiesel. A biodiesel conversion rate of up to $85 \%$ was achieved, and the results of the study showed that the biodiesel produced complied with standard SNI 7182: 2015 (2017)

After the pretreatment of cooking oil to reduce free fatty acids, a comparison of the efficiency of catalysts based on chicken eggshells and $\mathrm{CPH}$ was carried out for the production of biodiesel by transesterification (Andherson et al. 2018). The authors obtained $81.4 \%$ conversion of biodiesel with the chicken eggshell catalyst $(\mathrm{CaO})$ and obtained approximately $85 \%$ conversion of biodiesel with the reaction that used $\mathrm{K}_{2} \mathrm{CO}_{3}$ obtained from the cocoa pod husks (Andherson et al. 2018). Indeed, the use of heterogeneous catalysts from biomass to produce biodiesel seems to be a promising choice, as it eliminates the tedious tasks and problems of homogenous operations (Abdullah et al. 2017). However, more research on catalysts from cocoa residues is needed to improve the catalytic performance of biodiesel production and other chemical processes (Abdullah et al. 2017).

\section{Producing animal feed}

Recent studies have focused on the growth of pigs (Balentić et al. 2018). Magistrelli et al. (2016) showed that the use of CPH in pig feed can have a positive effect on the balance of the intestinal microbial ecosystem (Magistrelli et al. 2016). These studies were confirmed after analyzing the addition of $20 \% \mathrm{CPH}$ to pig feed (Ogunsipe et al. 2017). The authors showed that this rate was the optimal biological level for the use of $\mathrm{CPH}$ as an energy substitute for maize in pig feed (Ogunsipe et al. 2017). All of these studies demonstrate that $\mathrm{CPH}$ have a high potential for use as livestock feed to replace expensive conventional food ingredients.

\section{Bioenergies and biofuels}

The problems related to the use of fossil fuels require a transition to renewable energy sources (Chan and Choo 2013). Currently, the replacement of fossil fuels with renewable energies is increasing worldwide (Morato et al. 2019). The use of renewable resources and clean technologies remains a challenge for developing countries (Morato $e t$ al. 2019). Given the growing demand for energy, the search for other sources of energy production that are cheap, ecological, renewable, and suitable to replace fossil fuels is underway. Chan and Choo (2013) focused on the pyrolytic conversion of CPH in an electric thermal reactor of the fixed-bed type. The average calorific values of biofuel and biogas were improved compared to those obtained with other fuels, such as coal and ethanol (Chan and Choo 2013). However, Titiloye et al. (2013) showed that, during the thermochemical characterization of agricultural waste from West Africa, $\mathrm{CPH}$ would be better suited for biochemical conversion (Titiloye et al. 2013). This was confirmed by Mancini et al. (2016), as they showed that $\mathrm{CPH}$ have good potential for biogas production with accumulated methane yields. Likewise, Acosta et al. (2018) used CPH to produce methane. Their work consisted of evaluating the bioenergetic potential of $\mathrm{CPH}$ by anaerobic digestion (Acosta et al. 2018). Anaerobic digestion can stabilize organic matter and help retain nutrients 
(Acosta et al. 2018). Further, it can increase the value of water for land applications and reduce potential negative impacts (Acosta et al. 2018). This study showed the potential of cocoa waste as a source of renewable energy in rural areas (Acosta et al. 2018). However, the structural and mechanical properties of cocoa waste hinder enzymatic and microbial degradation and impede the optimal production of biogas. To propose a solution to this difficulty, Ward-Doria et al. (2016) compared the effectiveness of acid $\left(\mathrm{H}_{2} \mathrm{SO}_{4}\right)$ and alkaline $(\mathrm{NaOH})$ pretreatments on $\mathrm{CPH}$ to increase the potential for biogas production by anaerobic digestion. Alkaline pretreatment had the best results in terms of reducing the lignin content. Shet et al. (2018a) performed hydrolysis with hydrochloric acid ( $\mathrm{HCl})$ to release reducing sugars from CPH (Shet et al. 2018a). These sugars were obtained under optimal conditions and subjected to alcoholic fermentation by Pichia stipitis to produce bioethanol (Shet et al. 2018a). Further, the thermal conversion of CPH was performed by Adjin-Tetteh et al. (2018) as a potential source of agricultural waste for the production of bio-oil via a rapid pyrolysis process. Thermogravimetric analysis indicated that $\mathrm{CPH}$ is an excellent raw material for pyrolysis (Adjin-Tetteh et al. 2018). To find an alternative to petroleum-based fuels and overcome the sharp fluctuation in market prices, Sandesh et al. (2020) conducted a comparative study of induction heating and liquefied petroleum gas (LPG) for acid hydrolysis from cocoa pod biomass (CPB). In their study (Sandesh et al. 2020), the optimization of the sulfuric acid pretreatment was preceded by a response surface methodology that studied the effect of the amount of acid used, the load of the biomass, and the time of stay in the reactor. Finally, an anaerobic acetone-butanol-ethanol (ABE) fermentation using Clostridium acetobutilicum MTCC11274 was carried out to produce biobutanol from optimized factors. The results showed that induction heating was more efficient than LPG heating.

\section{Incorporating into food systems}

The food industry has begun using more ingredients from natural sources, which is required by regulations and requested by consumers (Azila et al. 2014). Cocoa pods husks, which are used as a substrate to produce functional components in the food industry, offer the possibility of developing a new chain of products with high added value. Indeed, the rich composition in dietary fibers and antioxidants of $\mathrm{CPH}$ has been shown (MartínezÁngel et al. 2015). Likewise, the nutritional quality of CPH was also evaluated by Kouakou et al. (2018) for plants and for humans. Analysis of the ash showed that CPH has a rich mineralogical composition (Kouakou et al. 2018). Cocoa pods husks could, therefore, contribute to the fight against hunger and malnutrition in cocoa-producing countries and be used as fertilizer for soils in rural areas. A study by Azila et al. (2014) demonstrated the utility of $\mathrm{CPH}$ as functional ingredients. In addition, $\mathrm{CPH}$ has great potential for use in body care products (Lu et al. 2018).

\section{Use in paper industry}

Much of global warming, soil erosion, and global climate change may be due to the large-scale deforestation of wood resources for the paper industry (Daud et al. 2013). Nonwood materials, such as $\mathrm{CPH}$, are potential sources of fiber to produce pulp and paper (Daud et al. 2013). Daud et al. (2014) showed that the skin of CPH had a high lignocellulose content with linear fibrillar arrangements. This characteristic improves the resistance properties of the pulp and paper produced (Daud et al. 2014). In addition, chemical compositions and morphological surface studies indicated that CPH pulp is comparable to that of wood; thus, $\mathrm{CPH}$ would be a suitable pulp for use in paper 
manufacturing industries (Daud et al. 2014). The authors conducted an additional study on the paper fibers of corn stalk and CPH (Daud et al. 2014). They showed an improved abundance of lignocellulosic substances from $\mathrm{CPH}$ and corn stalk, which could lead to improved fiber interfacial characteristics in papermaking.

\section{Use as natural filler in the formulation of biocomposites}

Recently, interest in the use of agricultural by-products as a natural filler in thermoplastic materials has arisen in research laboratories and industries (Chun et al. 2014b). Indeed, the use of natural fibers as reinforcement for composite materials can improve the properties or reduce the price of the final product. Efforts have been made by mixing and developing composites with other polymers and fillers (Helanto et al. 2019). In addition, composites based on natural fibers open up new outlets for agricultural products and promote the development of agro-materials and technologies that consider environmental impacts (Boudjema 2016). Natural fibers are valuable materials that have been produced and recycled naturally on earth for millions of years. They are biodegradable and renewable.

Cocoa pod husks are abundant in the Ivory Coast, as their annual production is estimated at over 50.25 billion pods (Kouakou et al. 2018). However, this biomass has no market value. In fact, $\mathrm{CPH}$ is typically thrown away as waste or composted to cultivate cocoa (Chun et al. 2014b). Using CPH as a reinforcing filler in biocomposites can generate economic benefits and reduce their ecological impact. However, the bonding strengths between agricultural waste reinforcements and polymer matrices are weak. Therefore, several strategies have been implemented to remedy this. Among them, the use of coupling agents to improve the charge-matrix interface and increase the thermo-mechanical properties of these biocomposites has been employed. In this context, the effect of the modification of the charge using methacrylic acid (MAA) on polypropylene composites (PP/CPH) was studied by Chun et al. (2013). These authors observed an increase in the stabilization torque, the crystallinity, and the thermal stability of PP/CPH composites. In addition, the strength and tensile modulus of the composites were improved (Koay et al. 2013). However, a reduction in elongation at break was observed. In another study, a biocomposite was developed by Chun et al. (2014b) from polypropylene and CPH to evaluate the effect of 3-aminopropyltriethoxysilane (3-APE) as a coupling agent in the treatment of CPH (Chun et al. 2014b). The treatment of CPH reduced the number of hydroxyl groups $(-\mathrm{OH})$ on the surface, thus imparting hydrophobic properties to the filler and improving the charge-matrix interaction. The authors found a decrease in tensile strength and an increase in the tensile modulus with the addition of $\mathrm{CPH}$ and the treatment. This study also revealed that changes in filler content and processing have no influence on the melting temperature of biocomposites (Chun et al. 2014b).

Work has also focused on the use of $\mathrm{CPH}$ as a filler in PP biocomposites (Chun et al. 2015), and the thermal properties and morphologies of PP/CPH biocomposites were studied (Chun et al. 2015). The effect of different contents of palm oil-based coupling agent (POCA) on the tensile and morphological properties of polypropylene composites with different contents of CPH fillers was studied by Chun et al. (2014a). The results showed that $3 \%$ content of POCA gave the best tensile properties. Though the elongation at break decreased when the agent content was less than 3\%, it began to increase beyond $3 \%$. Further, SEM analysis showed better dispersion for the treated CPH and better adhesion with the PP matrix. Imoisili et al. (2013) studied the mechanical properties of CPH in a thermosetting polymer matrix (epoxy resin). The test results showed that the tensile and 
flexural strength of the composite decreases as the volume fraction of the load decreases, and the tensile modulus of the composite increases as the volume fraction of the load increases (Imoisili 2013).

A Taguchi method approach was used to optimize the processing parameters of thermoplastic polyurethane (TPU) composites reinforced with $\mathrm{CPH}$ fibers (El-Shekeil et al. 2014b). The parameters were temperature, speed, processing time, and fiber content (El-Shekeil et al. 2014b). The ANOVA analysis results showed that fiber content was the most important parameter for producing TPU/CPHU (El-Shekeil et al. 2014b). After this optimization study, El-Shekeil et al. (2014a) analyzed the effect of CPH loading on the mechanical and morphological properties of TPU/CPH composites using the optimal parameters.

Battegazzore et al. (2014) proposed a simple method to separate three fractions of hazelnuts and CPH to use them as plasticizers for PLA and as load enhancers for PLA and PP. Application of the solution casting method to PLA composite films filled with CPH showed that increasing the $\mathrm{CPH}$ load from $0 \%$ to $10 \%$ significantly increased the tensile strength of the PLA/CPH composite (Sanyang et al. 2017). However, the further increase of $\mathrm{CPH}$ load to $15 \%$ decreased this resistance. Bioactive compounds extracted from $\mathrm{CPH}$ may have health benefits; therefore, they may be an alternative source of important components. Figure 9 summarizes the potential uses, current applications, and potential upgrades of $\mathrm{CPH}$.

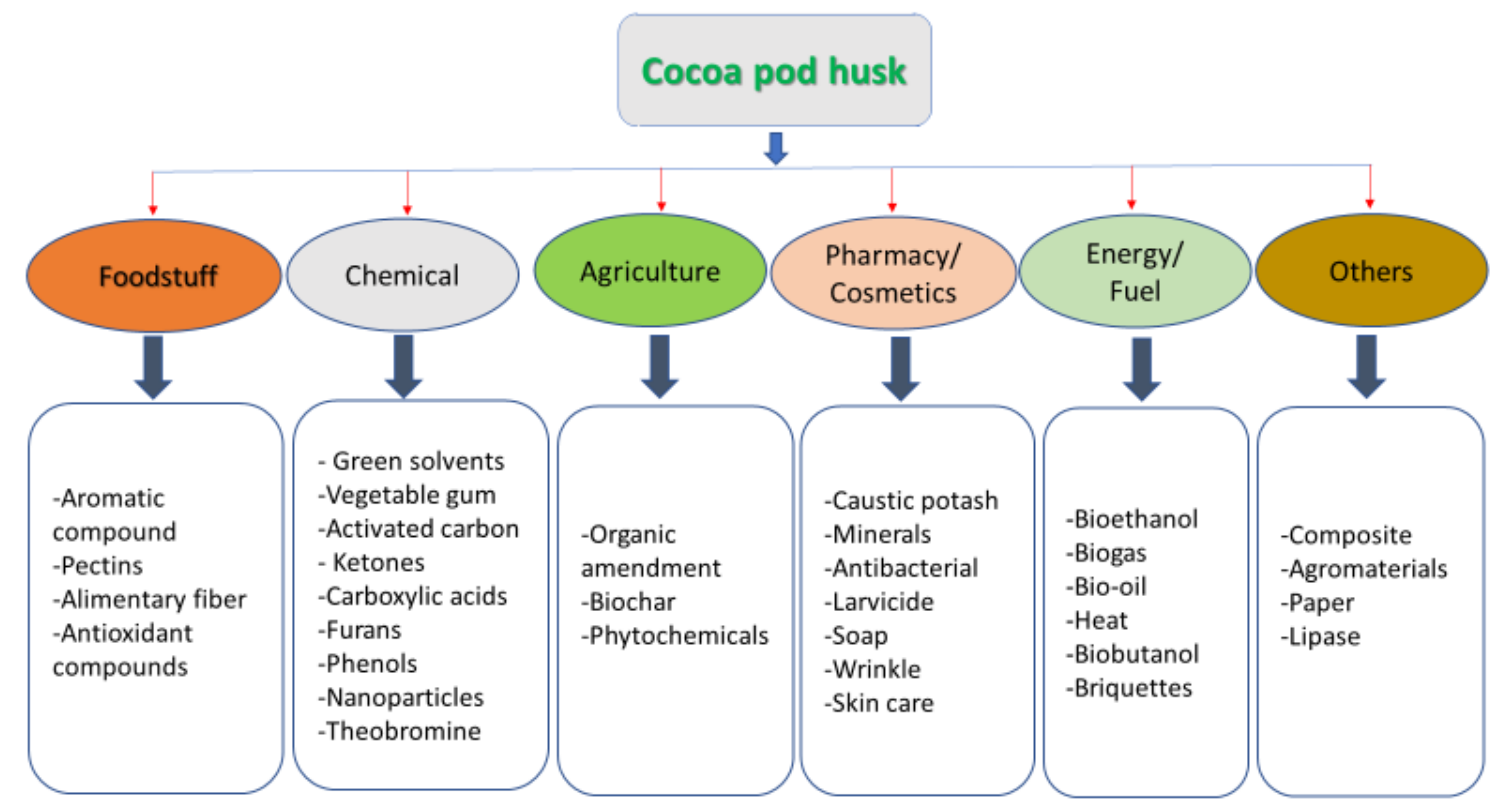

Fig. 9. Potential uses and applications of $\mathrm{CPH}$

\section{CONCLUSIONS}

1. The chemical, physico-chemical, and biochemical characterization of the cocoa pod husks $(\mathrm{CPH})$ has been carried out in numerous works. This step of the recovery process for this residue is crucial in order to understand the conversion processes. Indeed, it makes it possible to identify the most suitable recovery route and therefore the best uses of the material. 
2. Several studies have reported the use of cocoa pods husks in many fields, such as animal feed, cosmetics, and biodegradable composites. However, applications related to biotechnology and the use of $\mathrm{CPH}$ as feed are still under study. Many studies have given added value to $\mathrm{CPH}$ by using them as a natural filler in polymer composite materials. Their use offers good biodegradability to the final product.

3. However, due to the recalcitrance of lignocellulose, optimal $\mathrm{CPH}$ pretreatment processes should be implemented to separate the main components at relatively low temperatures and (if possible) without the use of chemical agents. These processes are necessary to prevent the main components, namely lignocellulose components, pectin, and phenolic compounds, from losing their functionality. These components can have applications in food systems by offering improved nutritional value and can provide high yields of energy sources or chemicals for industry. Further, the present literature review on $\mathrm{CPH}$ residues has highlighted applications and products with a high commercial value.

4. However, no studies have been conducted using $\mathrm{CPH}$ as a natural filler in polylactic acid biopolymers to develop composite materials that have better thermomechanical and morphological properties, are green and fully biodegradable, and can replace conventional plastics from fossil resources. Consequently, the development of processes that are easy to implement, less expensive, sustainable, and green, is a necessity. This will transform cocoa waste into products with high added value and meet current and future challenges. The problems associated with poor cocoa waste management could be considerably reduced by the recovery and biotransformation of the molecular compounds available in $\mathrm{CPH}$. Increased valorization of $\mathrm{CPH}$ will help to increase the overall sustainability of the cocoa agribusiness and open up a new source of income for cocoa farmers.

\section{ACKNOWLEDGMENTS}

The authors thank the International Development Research Center (IDRC) of Canada and the French Development Agency for their financial support.

\section{CONFLICTS OF INTEREST}

The authors declare that they have no conflict of interest.

\section{REFERENCES CITED}

Abdul Karim, A., Azlan, A., Ismail, A., Hashim, P., Salwa, Gani, S. S. A., Zainudin, B. H., and Abdullah, N. A. (2014a). "Phenolic composition, antioxidant, anti-wrinkles and tyrosinase inhibitory activities of cocoa pod extract," BMC Complementary and Alternative Medicine 14, Article number 381. DOI: 10.1186/1472-6882-14-381

Abdul Karim, A., Azlan, A., Ismail, A., Hashim, P., and Abdullah, N. A. (2014b). "Antioxidant properties of cocoa pods and shells," Malaysian Cocoa Journal 8, 49-56. 
Abdul Karim, A., Azlan, A., Ismail, A., Hashim, P., Gani, S. S. A., Zainudin, B. H., and Abdullah, N. A. (2016). "Efficacy of cocoa pod extract as antiwrinkle gel on human skin surface," Journal of Cosmetic Dermatology 15(3), 283-295. DOI:

10.1111/jocd.12218

Abdullah, S. H. Y. S., Hanapi, N. H. M., Azid, A., Umar, R., Juahir, H., Khatoon, H., and Endut, A. (2017). "A review of biomass-derived heterogeneous catalyst for a sustainable biodiesel production," Renewable and Sustainable Energy Reviews 70, 1040-1051. DOI: 10.1016/j.rser.2016.12.008

Acosta, N., de Vrieze, J., Sandoval, V., Sinche, D., Wierinck, I., and Rabaey, K. (2018).

"Cocoa residues as viable biomass for renewable energy production through anaerobic digestion," Bioresource Technology 265, 568-572. DOI:

10.1016/j.biortech.2018.05.100

Adewole, E., Ajiboye, B., Ojo, B., Ogunmodede, O. T., and Oso, O. (2015). "Characterization of cocoa (Theobroma cacao) pod," International Journal of Scientific \& Engineering Research 4(1), 1-6.

Adjin-Tetteh, M., Asiedu, N., Dodoo-Arhin, D., Karam, A., and Amaniampong, P. N. (2018). "Thermochemical conversion and characterization of cocoa pod husks a potential agricultural waste from Ghana," Industrial Crops and Products 119, 304312. DOI: $10.1016 / j$.indcrop.2018.02.060

Ahmad, F., Daud, W. M. A. W., Ahmad, M. A., and Radzi, R. (2013a). "The effects of acid leaching on porosity and surface functional groups of cocoa (Theobroma cacao)shell based activated carbon," Chemical Engineering Research and Design 91(6), 1028-1038. DOI: 10.1016/j.cherd.2013.01.003

Ahmad, F., Daud, W. M. A. W., Ahmad, M. A., Radzi, R., and Azmi, A. A. (2013b). "The effects of $\mathrm{CO}_{2}$ activation, on porosity and surface functional groups of cocoa (Theobroma cacao)-shell based activated carbon," Journal of Environmental Chemical Engineering 1(3), 378-388. DOI: 10.1016/j.jece.2013.06.004

Akinola, A. O., Eiche, J. F., Owolabi, P. O., and Elegbeleye, A. P. (2018). "Pyrolytic analysis of cocoa pod for biofuel production," Nigerian Journal of Technology 37(4), 1026-1031. DOI: 10.4314/njt.v37i4.23

Alemawor, F., Dzogbefia, V. P., Oddoye, E. O. K., and Oldham, J. H. (2009). "Effect of Pleurotus ostreatus fermentation on cocoa pod husk composition: Influence of fermentation period and $\mathrm{Mn}^{2+}$ supplementation on the fermentation process," African Journal of Biotechnology 8(9), 1950-1958. DOI: 10.4314/ajb.v8i9.60454

An, Y.-X., Zong, M.-H., Wu, H., and Li, N. (2015). "Pretreatment of lignocellulosic biomass with renewable cholinium ionic liquids: Biomass fractionation, enzymatic digestion and ionic liquid reuse," Bioresource Technology 192, 165-171. DOI: 10.1016/j.biortech.2015.05.064

Andherson, T., Rachmat, D., and Risanti, D. D. (2018). "Potential use of chicken egg shells and cacao pod husk as catalyst for biodiesel production," AIP Conference Proceedings 1945(1), Article ID 020058. DOI: 10.1063/1.5030280

Antwi, E., Engler, N., Nelles, M., and Schüch, A. (2019). "Anaerobic digestion and the effect of hydrothermal pretreatment on the biogas yield of cocoa pods," Waste Mangerment 88, 131-140. DOI: 10.1016/j.wasman.2019.03.034

Arevalo-Gallegos, A., Ahmad, Z., Asgher, M., Parra-Saldivar, R., and Iqbal, H. M. N. (2017). "Lignocellulose: A sustainable material to produce value-added products with a zero waste approach-A review," International Journal of Biological Macromolecules 99, 308-318. DOI: 10.1016/j.ijbiomac.2017.02.097 
Asiedu, N. Y., Neba, F. A., and Addo, A. (2019). "Modeling the attainable regions for catalytic oxidation of renewable biomass to specialty chemicals: Waste biomass to carboxylic acids," South African Journal of Chemical Engineering 30, 1-14. DOI: 10.1016/j.sajce.2019.07.003

Aslanzadeh, S., Berg, A., Taherzadeh, M. J., and Horváth, S. I. (2014). "Biogas production from N-methylmorpholine-N-oxide (NMMO) pretreated forest residues," Applied Biochemistry and Biotechnology 172(6), 2998-3008. DOI: 10.1007/s12010014-0747-z

Babatope, B. (2005). "Rheology of cocoa-pod husk aqueous system. Part-I: Steady state flow behavior," Rheologica Acta 45(1), 72-76. DOI: 10.1007/s00397-005-0450-7

Balentić, J. P., Ačkar, D., Jokić, S., Jozinović, A., Babić, J., Miličević, B., Šubarić, D., and Pavlović, N. (2018). "Cocoa shell: A by-product with great potential for wide application," Molecules 23(6), Article number 1404. DOI:

10.3390/molecules23061404

Battegazzore, D., Bocchini, S., Alongi, J., and Frache, A. (2014). "Plasticizers, antioxidants and reinforcement fillers from hazelnut skin and cocoa by-products: Extraction and use in PLA and PP," Polymer Degradation and Stability 108, 297306. DOI: 10.1016/j.polymdegradstab.2014.03.003

Bernaert, H. (2020). "Procedure for extracting pectin from CPH and application in the food, pharmaceutical and personal care industries," European Patent No. EP3613297A1.

Bernaert, H., and Kopp, G. (2020a). "Cacao pod husk powder, method of its preparation and its use in food, pharmaceutical and cosmetic compositions," World Intellectual Property Organization Patent No. WO2020038906A1.

Bernaert, H., and Kopp, G. (2020b). "Process to extract components of cacao pod husks and to utilize cacao fruit soluble extract obtained thereof and its applications," World Intellectual Property Organization Patent No. WO2020038905A1.

Beukes, N., and Pletschke, B. I. (2010). "Effect of lime pre-treatment on the synergistic hydrolysis of sugarcane bagasse by hemicellulases," Bioresource Technology 101(12), 4472-4478. DOI: 10.1016/j.biortech.2010.01.081

Boudjema, H. L. (2016). Development of Biodegradable Composite Materials Derived from Renewable Resources, Ph.D. Dissertation, University of Oran 2 Mohamed Ben Ahmed, Bir El Djir, Algeria.

Campos-Vega, R., Nieto-Figueroa, K. H., and Oomah, B. D. (2018). "Cocoa (Theobroma cacao L.) pod husk: Renewable source of bioactive compounds," Trends in Food Science \& Technology 81, 172-184. DOI: 10.1016/j.tifs.2018.09.022

Chan, S.-Y., and Choo, W.-S. (2013). "Effect of extraction conditions on the yield and chemical properties of pectin from cocoa husks," Food Chemistry 141(4), 3752-3758. DOI: 10.1016/j.foodchem.2013.06.097

Chandra, R. P., Arantes, V., and Saddler, J. (2015). "Steam pretreatment of agricultural residues facilitates hemicellulose recovery while enhancing enzyme accessibility to cellulose," Bioresource Technology 118, 302-307. DOI:

10.1016/j.biortech.2015.02.106

Chen, H., Liu, J., Chang, X., Chen, D., Xue, Y., Liu, P., Lin, H., and Han, S. (2017). “A review on the pretreatment of lignocellulose for high-value chemicals," Fuel Processing Technology 160, 196-206. DOI: 10.1016/j.fuproc.2016.12.007 
Chen, H.-Z., and Liu, Z.-H. (2015). "Steam explosion and its combinatorial pretreatment refining technology of plant biomass to bio-based products," Biotechnology Journal 10(6), 866-885. DOI: 10.1002/biot.201400705

Cho, E. J., Trinh, L. T. P., Song, Y., Lee, Y. G., and Bae, H.-J. (2020). "Bioconversion of biomass waste into high value chemicals," Bioresource Technology 298, Article ID 122386. DOI: 10.1016/j.biortech.2019.122386

Chun, K. S., and Husseinsyah, S. (2016). "Agrowaste-based composites from cocoa pod husk and polypropylene: Effect of filler content and chemical treatment," Journal of Thermoplastic Composite Materials 29(10), 1332-1351. DOI: 10.1177/0892705714563125

Chun, K. S., Husseinsyah, S., and Osman, H. (2014a). "Preliminary study of palm oil based coupling agent for polypropylene/cocoa pod husk composites," Advances in Environmental Biology 8(8), 2640-2644.

Chun, K. S., Husseinsyah, S., and Osman, H. (2014b). "Development of biocomposites from cocoa pod husk and polypropylene: Effect of filler content and 3-aminopropyltriethoxylsilane," Polymers from Renewable Resources 5(4), 139-156. DOI: $10.1177 / 204124791400500401$

Chun, K. S., Husseinsyah, S., and Osman, H. (2015). "Utilization of cocoa pod husk as filler in polypropylene biocomposites: Effect of maleated polypropylene," Journal of Thermoplastic Composite Materials 28(11), 1507-1521. DOI:

10.1177/0892705713513291

Cruz, G., Pirilä, M., Huuhtanen, M., Carrión, L., Alvarenga, E., and Keiski, R. L. (2012). "Production of activated carbon from cocoa (Theobroma cacao) pod husk," Journal of Civil \& Environmental Engineering 2(2), Article ID 1000109. DOI: 10.4172/2165784X.1000109

Dahunsi, S. O. (2019). "Mechanical pretreatment of lignocelluloses for enhanced biogas production: Methane yield prediction from biomass structural components," Bioresource Technology 280, 18-26. DOI: 10.1016/j.biortech.2019.02.006

Dahunsi, S. O., Adesulu-Dahunsi, A. T., and Izebere, J. O. (2019a). "Cleaner energy through liquefaction of Cocoa (Theobroma cacao) pod husk: Pretreatment and process optimization," Journal of Cleaner Production 226, 578-588. DOI: 10.1016/j.jclepro.2019.04.112

Dahunsi, S. O., Osueke, C. O., Olayanju, T. M. A., and Lawal, A. I. (2019b). "Codigestion of Theobroma cacao (Cocoa) pod husk and poultry manure for energy generation: Effects of pretreatment methods," Bioresource Technology 283, 229-241. DOI: 10.1016/j.biortech.2019.03.093

Daud, Z., Awang, H., Kassim, A. S. M., Hatta, M. Z. M., and Aripin, A. M. (2014). "Cocoa pod husk and corn stalk: Alternative paper fibres study on chemical characterization and morphological structures," Advanced Materials Research 911, 331-335. DOI: 10.4028/www.scientific.net/AMR.911.331

Daud, Z., Kassim, A. S. M., Aripin, A. M., Awang, H., and Hatta, M. Z. M. (2013). "Chemical composition and morphological of cocoa pod husks and cassava peels for pulp and paper production," Australian Journal of Basic and Applied Sciences 7(9), 406-411.

Djeke, M. D., Angui, P. K. T., and Kouadio, J. Y. (2011). "Décomposition des broyats de coques de cacao dans les sols ferrallitiques de la zone d'Oumé, centre-ouest de la Côte d'Ivoire : Effets sur les caractéristiques chimiques des sols [Decomposition of ground cocoa shells in ferrallitic soils in the Oumé zone, west-central Côte d'Ivoire: 
Effects on soil chemical characteristics]," Biotechnology, Agronomy, Society and Environment 15(1), 109-117.

Doungous, O., Minyaka, E., Longue, E. A. M., and Nkengafac, N. J. (2018). "Potentials of cocoa pod husk-based compost on Phytophthora pod rot disease suppression, soil fertility, and Theobroma cacao L. growth," Environmental Science and Pollution Research International 25(25), 25327-25335. DOI: 10.1007/s11356-018-2591-0

Drevici, U., and Drevici, N. (1980). "Complete utilization of cocoa fruits and products," U. S. Patent No. US4206245A.

El-Shekeil, Y. A., Sapuan, S. M., and Algrafi, M. W. (2014a). "Effect of fiber loading on mechanical and morphological properties of cocoa pod husk fibers reinforced thermoplastic polyurethane composites," Materials \& Design 64, 330-333. DOI: 10.1016/j.matdes.2014.07.034

El-Shekeil, Y. A., Sapuan, S. M., and Haron, M. (2014b). "Optimization of processing parameters and fiber content of cocoa pod husk fiber-reinforced thermoplastic polyurethane composites by Taguchi method," Applied Mechanics and Materials 564, 394-399. DOI: 10.4028/www.scientific.net/AMM.564.394

Fidelis, C., and Rao, B. K. R. (2017). "Enriched cocoa pod composts and their fertilizing effects on hybrid cocoa seedlings," International Journal of Recycling of Organic Waste in Agriculture 6(2), 99-106. DOI: 10.1007/s40093-017-0156-8

Fioresi, F., Vieillard, J., Bargougui, R., Bouazizi, N., Fotsing, P. N., Woumfo, E. D., Brun, N., Mofaddel, N., and Le Derf, F. (2017). "Chemical modification of the cocoa shell surface using diazonium salts," Journal of Colloid and Interface Science 494, 92-97. DOI: 10.1016/j.jcis.2017.01.069

Forero Nuñez, C. A., Jochum, J., and Sierra-Vargas, F. E. (2015). "Effect of particle size and addition of cocoa pod husk on the properties of sawdust and coal pellets," Ingeniería e Investigación 35(1), 17-23. DOI: 10.15446/ing.investig.v35n1.46157

Giwa, A. S., Ali, N., Vakili, M., Guo, X., Liu, D., and Wang, K. (2020). “Opportunities for holistic waste stream valorization from food waste treatment facilities: A review," Reviews in Chemical Engineering 1(Preprint), Online. DOI: 10.1515/revce-20190064

Gyedu-Akoto, E., Yabani, D., Sefa, J., and Owusu, D. (2015). "Natural skin-care products: The case of soap made from cocoa pod husk potash," Advances in Research 4(6), 365-370. DOI: 10.9734/AIR/2015/17029

Hale, S. E., Alling, V., Martinsen, V., Mulder, J., Breedveld, G. D., and Cornelissen, G. (2013). "The sorption and desorption of phosphate-P, ammonium-N and nitrate- $\mathrm{N}$ in cacao shell and corn cob biochars," Chemosphere 91(11), 1612-1619. DOI: 10.1016/j.chemosphere.2012.12.057

Helanto, K., Matikainen, L., Talja, R., and Rojas, O. J. (2019). "Bio-based polymers for sustainable packaging and biobarriers: A critical review," BioResources 14(2), 49024951. DOI: 10.15376/biores.14.2.Helanto

Hernández-Hernández, C., Morales-Sillero, A., Fernández-Bolaños, J., Bermúdez-Oria, A., Morales, A. A., and Rodríguez-Gutiérrez, G. (2019). "Cocoa bean husk: Industrial source of antioxidant phenolic extract," Journal of the Science of Food and Agriculture 99(1), 325-333. DOI: 10.1002/jsfa.9191

Hernández-Hernández, C., Viera-Alcaide, I., Morales-Sillero, A. M., Fernández-Bolaños, J., and Rodríguez-Gutiérrez, G. (2018). "Bioactive compounds in Mexican genotypes of cocoa cotyledon and husk," Food Chemistry 240, 831-839. DOI: 10.1016/j.foodchem.2017.08.018 
Ibiremo, O. S., and Akanbi, O. S. O. (2015). "Comparative assessment of cocoa pod husk biochar fortified with NPK fertilizer formulations on kola seedling nutrient uptake and soil properties in Ibadan, Nigeria," International Journal of Plant \& Soil Science 6(5), 303-309. DOI: 10.9734/IJPSS/2015/16111

Imoisili, P. E., Ezenwafor, T. C., AttahDaniel, B. E., and Olusunle, S. O. O. (2013). "Mechanical properties of cocoa-pod/epoxy composite; Effect of filler fraction," American Chemical Science Journal 3(4), 526-531. DOI: 10.9734/ACSJ/2013/5526

International Cocoa Organization (ICCO) (2019). "May 2019 quarterly bulletin of cocoa statistics," International Cocoa Organization

(ICCO), (https://www.icco.org/about-us/icco-news/408-may-2019-quarterly-bulletinof-cocoa-statistics.html), Accessed 10 Sept 2020.

Jimat, D. Z., Salim, W. W. A. W., Aviceena, A., and Zailani, I. S. A. (2016). "Extraction of microcrystalline cellulose (MCC) from cocoa pod husk via alkaline pretreatment combined with ultrasonication," International Journal of Applied Engineering Research 11(19), 9876-9879.

Khanahmadi, S., Yusof, F., Amid, A., Mahmod, S. S., and Mahat, M. K. (2015). "Optimized preparation and characterization of CLEA-lipase from cocoa pod husk," Journal of Biotechnology 202, 153-161. DOI: 10.1016/j.jbiotec.2014.11.015

Khanahmadi, S., Yusof, F., Ong, H. C., Amid, A., and Shah, H. (2016). “Cocoa pod husk: A new source of CLEA-lipase for preparation of low-cost biodiesel: An optimized process," Journal of Biotechnology 231, 95-105. DOI:

10.1016/j.jbiotec.2016.05.015

Kilama, G., Lating, P. O., Byaruhanga, J., and Biira, S. (2019). "Quantification and characterization of cocoa pod husks for electricity generation in Uganda," Energy, Sustainability and Society 9, Article number 22. DOI: 10.1186/s13705-019-0205-4

Koay, S. C., Husseinsyah, S., and Osman, H. (2013). "Modified cocoa pod husk-filled polypropylene composites by using methacrylic acid," BioResources 8(3), 32603275. DOI: 10.15376/biores.8.3.3260-3275

Kouakou, E. K., Amed, C., Kouakou, F. K., Konan, C. M., Mouroufie, A. K., Kpan, E. S., Bouafou, K. G., and Kati-Coulibaly, S. (2018). "Cocoa pod in the Ivorian plantations: Green gold neglected and bulky?” Nutrition \& Food Science 7(2), 1-3. DOI: 10.19080/NFSIJ.2018.07.555709

Laconi, E. B., and Jayanegara, A. (2015). "Improving nutritional quality of cocoa pod (Theobroma cacao) through chemical and biological treatments for ruminant feeding: In vitro and in vivo evaluation," Asian-Australasian Journal of Animal Sciences 28(3), 343-350. DOI: 10.5713/ajas.13.0798

Laser, M., Schulman, D., Allen, S. G., Lichwa, J., Antal, M. J., and Lynd, L. R. (2002). "A comparison of liquid hot water and steam pretreatments of sugar cane bagasse for bioconversion to ethanol," Bioresource Technology 81(1), 33-44. DOI: 10.1016/S0960-8524(01)00103-1

Laurens, L. M. L., Nagle, N., Davis, R., Sweeney, N., Van Wychen, S., Lowell, A., and Pienkos, P. T. (2015). "Acid-catalyzed algal biomass pretreatment for integrated lipid and carbohydrate-based biofuels production," Green Chemistry 17(2), 1145-1158. DOI: 10.1039/C4GC01612B

Lo, K. V., Srinivasan, A., Liao, P. H., and Bailey, S. (2015). "Microwave oxidation treatment of sewage sludge," Journal of Environmental Science and Health, Part A 50(8), 882-889. DOI: 10.1080/10934529.2015.1019811 
López-Linares, J. C., Ballesteros, I., Tourán, J., Cara, C., Castro, E., Ballesteros, M., and Romero, I. (2015). "Optimization of uncatalyzed steam explosion pretreatment of rapeseed straw for biofuel production," Bioresource Technology 190, 97-105. DOI: 10.1016/j.biortech.2015.04.066

Lu, F., Rodriguez-Garcia, J., Van Damme, I., Westwood, N. J., Shaw, L., Robinson, J. S., Warren, G., Chatzifragkou, A., Mason, S. M., and Gomez, L., et al. (2018). "Valorisation strategies for cocoa pod husk and its fractions," Current Opinion in Green and Sustainable Chemistry 14, 80-88. DOI: 10.1016/j.cogsc.2018.07.007

Maassen, S. (2016). "Bibliometric analysis of research on wastewater irrigation during 1991-2014," Irrigation and Drainage 65(5), 644-653. DOI: 10.1002/ird.1981

Magistrelli, D., Zanchi, R., Malagutti, L., Galassi, G., Canzi, E., and Rosi, F. (2016). "Effects of cocoa husk feeding on the composition of swine intestinal microbiota," Journal of Agricultural and Food Chemistry 64(10), 2046-2052. DOI: 10.1021/acs.jafc.5b05732

Maleka, D. (2016). Assessment of the Implementation of Alternative Process Technologies for Rural Heat and Power Production from Cocoa Pod Husks, Master's Thesis, KTH Royal Institute of Technology, Stockholm, Sweden.

Mancini, G., Papirio, S., Lens, P. N. L., and Esposito, G. (2016). "Effect of N methylmorpholine-N-oxide pretreatment on biogas production from rice straw, cocoa shell, and hazelnut skin," Environmental Engineering Science 33(11), 843-850. DOI: 10.1089/ees.2016.0138

Mansur, D., Tago, T., Masuda, T., and Abimanyu, H. (2014). "Conversion of cacao pod husks by pyrolysis and catalytic reaction to produce useful chemicals," Biomass and Bioenergy 66, 275-285. DOI: 10.1016/j.biombioe.2014.03.065

Manzoor, Q., Nadeem, R., Iqbal, M., Saeed, R., and Ansari, T. M. (2013). "Organic acids pretreatment effect on Rosa bourbonia phyto-biomass for removal of $\mathrm{Pb}$ (II) and $\mathrm{Cu}(\mathrm{II})$ from aqueous media," Bioresource Technology 132, 446-452. DOI: 10.1016/j.biortech.2013.01.156

Marsiglia, D. E., Ojeda, K. A., Ramirez, M. C., and Sánchez, E. (2016). "Pectin extraction from cocoa pod husk (Theobroma cacao L.) by hydrolysis with citric and acetic acid," International Journal of Chemtech Research 9(7), 497-507.

Martínez-Ángel, J. D., Villamizar-Gallardo, R. A., and Ortíz-Rodríguez, O. O. (2015). "Characterization and evaluation of cocoa (Theobroma cacao L.) pod husk as a renewable energy source," Agrociencia 49(3), 329-345.

Mirmohamadsadeghi, S., Chen, Z., and Wan, C. (2016). "Reducing biomass recalcitrance via mild sodium carbonate pretreatment," Bioresource Technology 209, 386-390. DOI: 10.1016/j.biortech.2016.02.096

Monge, J. A. (2015). "Method for the synthesis of active carbon monoliths from cacao skin," World Intellectual Property Organization Patent No. WO 2015/018957 Al.

Monge, J. A. (2016). "Procedure and synthesis of activated carbon monoliths from cocoa husk," Spanish Office of the Patents and Brand Patent No. ES 2539845 B1.

Morales, L., Calderon, J., Solórzano, W., and Alvarado, I. (2019). "Modeling of cocoa pod husk anaerobic digester using artificial neural networks," in: 2019 IEEE XXVI International Conference on Electronics, Electrical Engineering and Computing (INTERCON), Lima, Peru, pp. 1-4.

Morato, T., Vaezi, M., and Kumar, A. (2019). "Assessment of energy production potential from agricultural residues in Bolivia," Renewable and Sustainable Energy Reviews 102, 14-23. DOI: 10.1016/j.rser.2018.11.032 
Mosier, N., Hendrickson, R., Ho, N., Sedlak, M., and Ladisch, M. R. (2005). "Optimization of $\mathrm{pH}$ controlled liquid hot water pretreatment of corn stover," Bioresource Technology 96(18), 1986-1993. DOI: 10.1016/j.biortech.2005.01.013

Munongo, M. E., Nkeng, G. E., and Njukeng, J. N. (2017). "Production and characterization of compost manure and biochar from cocoa pod husks," International Journal of Advanced Scientific Research and Management 2(2), 26-31.

Nazir, N., Novelina, Juita, E., Amelia, C., and Fatli, R. (2016). "Optimization of pretreatment process of cocoa pod husk using various chemical solvents," International Journal on Advanced Science, Engineering and Information Technology 6(3), 403409. DOI: 10.18517/ijaseit.6.3.848

Odubiyi, O. A., Awoyale, A. A., and Eloka-Eboka, A. C. (2012). "Wastewater treatment with activated charcoal produced from cocoa pod husk," International Journal of Environment and Bioenergy 4(3), 162-175.

Ofori, P., and Akoto, O. (2020). "Production and characterisation of briquettes from carbonised cocoa pod husk and sawdust," Open Access Library Journal 7, e6029. DOI: 10.4236/oalib.1106029

Ofori-Boateng, C., and Lee, K. T. (2013). "The potential of using cocoa pod husks as green solid base catalysts for the transesterification of soybean oil into biodiesel: Effects of biodiesel on engine performance," Chemical Engineering Journal 220, 395-401. DOI: 10.1016/j.cej.2013.01.046

Ogunjobi, J. K., and Lajide, L. (2015). "The potential of cocoa pods and plantain peels as renewable sources in Nigeria," International Journal of Green Energy 12(4), 440445. DOI: 10.1080/15435075.2013.848403

Ogunsipe, M. H., Ibidapo, I., Oloruntola, O. D., and Agbede, J. O. (2017). "Growth performance of pigs on dietary cocoa bean shell meal," Livestock Research for Rural Development 29(1), 1-5.

Onyegbado, C. O., Iyagba, E. T., and Offor, O. J. (2002). "Solid soap production using plantain peel ash as source of alkali," Journal of Applied Sciences and Environmental Management 6(1), 73-77. DOI: 10.4314/jasem.v6i1.17200

Pereira, R. G., Veloso, C. M., da Silva, N. M., de Sousa, L. F., Bonomo, R. C. F., de Souza, A. O., da Guarda Souza, M. O., and da Costa Ilhéu Fontan, R. (2014). "Preparation of activated carbons from cocoa shells and siriguela seeds using $\mathrm{H}_{3} \mathrm{PO}_{4}$ and $\mathrm{ZnCl}_{2}$ as activating agents for BSA and $\alpha$-lactalbumin adsorption," Fuel Processing Technology 126, 476-486. DOI: 10.1016/j.fuproc.2014.06.001

Priyangini, F., Walde, S. G., and Chidambaram, R. (2018). "Extraction optimization of pectin from cocoa pod husks (Theobroma cacao L.) with ascorbic acid using response surface methodology," Carbohydrate Polymers 202, 497-503. DOI: 10.1016/j.carbpol.2018.08.103

Pua, F. L., Sajab, M. S., Chia, C. H., Zakaria, S., Rahman, I. A., and Salit, M. S. (2013). "Alkaline-treated cocoa pod husk as adsorbent for removing methylene blue from aqueous solutions," Journal of Environmental Chemical Engineering 1(3), 460-465. DOI: 10.1016/j.jece.2013.06.012

Rachmawaty, Mu'nisa, A., Hasri, Pagarra, H., Hartati, and Maulana, Z. (2018). “Active compounds extraction of cocoa pod husk (Theobroma cacao L.) and potential as fungicides," in: $2^{\text {nd }}$ International Conference on Statistics, Mathematics, Teaching, and Research, Makassar, Indonesia, pp. 1-7. 
Rahman, R. N. Z. R. A., Salleh, A. B., Basri, M., and Samad, M. Y. A. (2014). "Biofertilizer," World Intellectual Property Organization Patent No. WO 2014/042517 A2.

Rastegari, A. A., Yadav, A. N., and Gupta, A. (2019). Prospects of Renewable Bioprocessing in Future Energy Systems, Springer International Publishing, Cham, Switzerland.

Rezania, S., Din, M. F., Mohamad, S. E., Sohaili, J., Taib, S. M., Yusof, M. B. M., Kamyab, H., Darajeh, N., and Ahsan, A. (2017). "Review on pretreatment methods and ethanol production from cellulosic water hyacinth," BioResources 12(1), 21082124. DOI: 10.15376/biores.12.1.Rezania

Sandesh, K., Shishir, R. K., and Vaman Rao, C. (2020). "Optimization and comparison of induction heating and LPG assisted acid pretreatment of cocoa pod for ABE fermentation," Fuel 262, Article ID 116499. DOI: 10.1016/j.fuel.2019.116499

Sanyang, M. L., Sapuan, S. M., and Haron, M. (2017). "Effect of cocoa pod husk filler loading on tensile properties of cocoa pod husk/polylactic acid green biocomposite films," AIP Conference Proceedings 1891(1), Article ID 020126. DOI: $10.1063 / 1.5005459$

Saratale, G. D., Jung, M.-Y., and Oh, M.-K. (2016). "Reutilization of green liquor chemicals for pretreatment of whole rice waste biomass and its application to 2,3butanediol production," Bioresource Technology 205, 90-96. DOI: 10.1016/j.biortech.2016.01.028

Shet, V. B., Nisha, Bhat, M., Manasa, Mascarenhas, L. N. S., Goveas, L. C., Rao, C. V., and Ujwal, P. (2016). "Optimization of $\mathrm{Na}_{2} \mathrm{CO}_{3}$ pre-treatment by RSM approach for releasing reducing sugars from cocoa pod shells," in: Biotechnology and Biochemical Engineering, B. D. Prasanna, N. G. Sathyanarayana, and P. V. Vadlani (eds.), Springer Singapore, East Singapore, Singapore, pp. 85-91.

Shet, V. B., Sanil, N., Bhat, M., Naik, M., Mascarenhas, L. N., Goveas, L. C., Rao, C. V., Ujwal, P., Sandesh, K., and Aparna, A. (2018a). "Acid hydrolysis optimization of cocoa pod shell using response surface methodology approach toward ethanol production," Agriculture and Natural Resources 52(6), 581-587. DOI: 10.1016/j.anres.2018.11.022

Shet, V. B., Shetty, V. C., Siddik, A., Rakshith, K. G., Shetty, N. J., Goveas, L. C., D’Mello, G., Rao, C. V., Ujwal, P., and Aparna, A. (2018b). “Optimization of microwave assisted $\mathrm{H}_{2} \mathrm{SO}_{4}$ hydrolysis of cocoa pod shells: Comparison between response surface methodology and artificial neural network and production of bioethanol thereof," Journal of Microbiology, Biotechnology and Food Sciences 7(5), 473-477. DOI: 10.15414/jmbfs.2018.7.5.473-477

SNI 7182-2015 (2017). "Biodiesel specification in Indonesia," Indonesian Association of BioEnergy Scientists and Technologists, Pathumtani, Thailand.

Statista (2019). "Cocoa beans: World production by country 2016-2019," Statista, (https://fr.statista.com/statistiques/565101/production-mondiale-feves-cacao-volumepar-pays/), Accessed 11 April 2020.

Syamsiro, M., Saptoadi, H., Tambunan, B. H., and Pambudi, N. A. (2012). "A preliminary study on use of cocoa pod husk as a renewable source of energy in Indonesia," Energy for Sustainable Development 16(1), 74-77. DOI:

10.1016/j.esd.2011.10.005 
Taherzadeh, M. J., and Karimi, K. (2008). "Pretreatment of lignocellulosic wastes to improve ethanol and biogas production: A review," International Journal of Molecular Sciences 9(9), 1621-1651. DOI: 10.3390/ijms9091621

Taiwo, O. E., and Osinowo, F. A. O. (2001). "Evaluation of various agro-wastes for traditional black soap production," Bioresource Technology 79(1), 95-97. DOI: 10.1016/S0960-8524(00)00188-7

Tejada, C. N., Almanza, D., Villabona, A., Colpas, F., and Granados, C. (2017). "Characterization of activated carbon synthesized at low temperature from cocoa shell (Theobroma cacao) for adsorbing amoxicillin," Ingeniería y Competitividad 19(2), 45-54. DOI: 10.25100/iyc.v19i2.5292

Thamsee, T., Choojit, S., Cheirsilp, B., Yamseangsung, R., Ruengpeerakul, T., and Sangwichien, C. (2019). "Combination of superheated steam explosion and alkaline autoclaving pretreatment for improvement of enzymatic digestibility of the oil palm tree residues as alternative sugar sources," Waste and Biomass Valorization 10(10), 3009-3023. DOI: 10.1007/s12649-018-0292-z

Titiloye, J. O., Bakar, M. S. A., and Odetoye, T. E. (2013). "Thermochemical characterisation of agricultural wastes from West Africa," Industrial Crops and Products 47, 199-203. DOI: 10.1016/j.indcrop.2013.03.011

Tovar, C. T., Ortíz, A. V., Avila, A. C., Acevedo, D., and Gómez, N. P. (2018). “Kinetics and modelling of drug adsorption using activated carbon derived from cocoa cob waste," International Journal of Chemtech Research 11(5), 149-160. DOI: 10.20902/IJCTR.2018.110516

Tsai, C.-H., Tsai, W.-T., Liu, S.-C., and Lin, Y.-Q. (2017). "Thermochemical characterization of biochar from cocoa pod husk prepared at low pyrolysis temperature," Biomass Conversion and Biorefinery 8, 237-243. DOI: 10.1007/s13399-017-0259-5

Tsai, W.-T., and Huang, P.-C. (2018). "Characterization of acid-leaching cocoa pod husk $(\mathrm{CPH})$ and its resulting activated carbon," Biomass Conversion and Biorefinery 8 , 521-528. DOI: 10.1007/s13399-018-0302-1

Tsai, W.-T., Hsu, C.-H., Lin, Y.-Q., Tsai, C.-H., Chen, W.-S., and Chang, Y.-T. (2020). "Enhancing the pore properties and adsorption performance of cocoa pod husk (CPH)-derived biochars via post-acid treatment," Processes 8(2), 144-157. DOI: 10.3390/pr8020144

Umagiliyage, A. L., Choudhary, R., Liang, Y., Haddock, J., and Watson, D. G. (2015). "Laboratory scale optimization of alkali pretreatment for improving enzymatic hydrolysis of sweet sorghum bagasse," Industrial Crops and Products 74, 977-986. DOI: 10.1016/j.indcrop.2015.05.044

Uy, J. R., Careo, N. D., Llarena, D., and Barajas, J. R. (2019). "Optimization of furfural extraction from Theobrama cacao wastes using response surface methodology," MATEC Web of Conferences 268, Article ID 06010. DOI: $10.1051 /$ matecconf/201926806010

Valadez-Carmona, L., Ortiz-Moreno, A., Ceballos-Reyes, G., Mendiola, J. A., and Ibáñez, E. (2018). "Valorization of cacao pod husk through supercritical fluid extraction of phenolic compounds," The Journal of Supercritical Fluids 131, 99-105. DOI: 10.1016/j.supflu.2017.09.011

Vásquez, Z. S., de Carvalho Neto, D. P., Pereira, G. V. M., Vandenberghe, L. P. S., de Oliveira, P. Z., Tiburcio, P. B., Rogez, H. L. G., Neto, A. G., and Soccol, C. R. 
(2019). "Biotechnological approaches for cocoa waste management: A review," Waste Management 90, 72-83. DOI: 10.1016/j.wasman.2019.04.030

Vriesmann, L. C., de Mello Castanho Amboni, R. D., and de Oliveira Petkowicz, C. L. (2011a). "Cacao pod husks (Theobroma cacao L.): Composition and hot-watersoluble pectins," Industrial Crops and Products 34(1), 1173-1181. DOI: 10.1016/j.indcrop.2011.04.004

Vriesmann, L. C., and de Oliveira Petkowicz, C. L. (2017). "Cacao pod husks as a source of low-methoxyl, highly acetylated pectins able to gel in acidic media," International Journal of Biological Macromolecules 101, 146-152. DOI: 10.1016/j.ijbiomac.2017.03.082

Vriesmann, L. C., Teófilo, R. F., and de Oliveira Petkowicz, C. L (2011b). “Optimization of nitric acid-mediated extraction of pectin from cacao pod husks (Theobroma cacao L.) using response surface methodology," Carbohydrate Polymers 84(4), 1230-1236. DOI: 10.1016/j.carbpol.2011.01.009

Wang, Y., Tashiro, Y., and Sonomoto, K. (2015). "Fermentative production of lactic acid from renewable materials: Recent achievements, prospects, and limits," Journal of Bioscience and Bioengineering 119(1), 10-18. DOI: 10.1016/j.jbiosc.2014.06.003

Ward-Doria, M., Arzuaga-Garrido, J., Ojeda, K. A., and Sánchez, E. (2016). "Production of biogas from acid and alkaline pretreated cocoa pod husk (Theobroma cacao L.)," International Journal of Chemtech Research 9(11), 252-260.

Woiciechowski, A. L., Neto, C. J. D., de Souza Vandenberghe, L. P., de Carvalho Neto, D. P., Sydney, A. C. N., Letti, L. A. J., Karp, S. G., Torres, L. A. Z., and Soccol, C. R. (2020). "Lignocellulosic biomass: Acid and alkaline pretreatments and their effects on biomass recalcitrance - Conventional processing and recent advances," Bioresource Technology 304, Article ID 122848. DOI: 10.1016/j.biortech.2020.122848

Wyman, C. E., Dale, B. E., Elander, R. T., Holtzapple, M., Ladisch, M. R., and Lee, Y. Y. (2005). "Coordinated development of leading biomass pretreatment technologies," Bioresource Technology 96(18), 1959-1966. DOI: 10.1016/j.biortech.2005.01.010

Article submitted: August 12, 2020; Peer review completed: October 18, 2020; Revised version received and accepted: October 27, 2020; Published: November 2, 2020.

DOI: 10.15376/biores.16.1.Ouattara 